\title{
Hydrogeological Modelling of Oil Contaminated Site in Valmiera
}

\section{Hidroǵeologiskā modelēšana naftas produktu piesārņojumam Valmierā}

\author{
Aivars Spalviņš ${ }^{1}$, Kaspars Krauklis $^{2}$, Inta Lāce ${ }^{3}$, Daiga Pipira ${ }^{4}$, Sandra Karuša ${ }^{5}$, Inga Retiķe ${ }^{6}$, \\ Madara Mame ${ }^{7}$, Linda Fībiga ${ }^{8}$ \\ ${ }^{1-3}$ Rīgas Tehniskā universitāte, Latvija, \\ 4-8 VSIA "Latvijas Vides, geologijas un meteorologijas centrs", Latvija
}

\begin{abstract}
Kopsavilkums - Valmieras bijušās mazuta bāzes teritorija ir piesārņota ar naftas produktiem, un vieta nav reg̣istrēta kā piesārṇota vai potenciāli piesārṇota vieta (PPPV), tomēr projekta "INSURE" (CB Nr. 39) ietvaros tika plānots novērtēt iespējamo teritorijas ietekmi uz apkārtējo vidi. No 2016. gada līdz 2017. gadam SIA "Vides konsultāciju birojs" izpētīja bāzes teritorijas pazemes ūdeṇu un grunts piesārṇojumu. Izmantojot datus par pazemes ūdens piesārņojumu ar naftas produktiem, Valsts SIA "Latvijas Vides, ǵeoloğijas un meteoroloğijas centrs" kopā ar Rīgas Tehnisko universitāti izveidoja piesānnotās teritorijas hidrogeoloğisko modeli. Noskaidrots, ka piesārṇotais pazemes ūdens var sasniegt Gaujas upi aptuveni 60 gadu laikā. Bāzes apkārtnē, mālsmiltī, pazemes ūdens pārvar tikai 40 metrus 15 gados, bet $1,8 \mathrm{~km}$ līdz upei smilšakmenī noceḷo 45 gados. Pirmajos 15 gados naftas produktu koncentrācija samazinās vismaz 60 reižu. Iespējama būtiska piesārṇojuma masas samazināšanās mikroorganismu darbības ietekmē. Modelēšanas rezultāti pārliecina, ka naftas produktu piesārṇojums pazemes ūdenī bijušajā mazuta bāzē praktiski neietekmē vides kvalitāti. Hidroǵeologiskā un masu transporta modeḷu veidošanas un izmantošanas aprakstus var izmantot modelēšanas speciālisti pazemes ūdens piesārṇojumu izpētes metožu pilnveidošanai.
\end{abstract}

Atslēgas vārdi - Hidroǵgeoloğiskais modelis, naftas produkti, pazemes ūdens piesārṇojums.

\section{IEVADS}

Centrālā Baltijas reǵiona pārrobežu sadarbības projekta Nr. CB 39 “INSURE” (Inovatîva ilgtspējīga attīrīšana) ietvaros viens no uzdevumiem bija veikt izpēti Valmieras bijušās mazuta bāzes teritorijā, kas atrodas Kaugurmuižā, $1,8 \mathrm{~km}$ attālumā no Gaujas upes (skat. 1. un 2. att.). Saskaṇā ar Valmieras pilsētas pašvaldības noslēgto līgumu naftas produktu piesārṇojuma izpēti 2016.-2017. gadā veica SIA "Vides konsultāciju birojs" (VKB). Lai novērtētu pazemes ūdens piesārṇojuma ietekmi uz apkārtējo vidi, Valsts SIA "Latvijas Vides, ǵeologijas un meteoroloğijas centrs" (LVG̣MC) kopā ar Rīgas Tehnisko universitāti (RTU) izveidoja lokālu hidroǵeoloǵisku modeli (HM). Tas izveidots, izmantojot ǵeoloǵiskās izpētes mateiālus, LVG̣MC datubāzes "URBUMI" un - datu nepietiekamības gadijumā - Latvijas hidroǵeoloǵiskā modeḷa (LAMO4) datus [1], un tas aizṇem
$2500 \mathrm{~m} \times 2800 \mathrm{~m}$ laukumu. Modela plaknes aproksimācijas režǵa solis ir $10 \mathrm{~m}$ (LAMO4 solis $250 \mathrm{~m})$.

Modelis veidots ar programmatūras "Groundwater Vistas 6" (GV) [2] MODFLOW rīku [3]. Naftas produktu kustība pazemes ūden̄i modelēta ar $G V$ rīkiem $M O D P A T H$ [4] un $M T 3 D$ [5], kuri izmanto ar MODFLOW aprēkinātos datus par telpiskām pazemes plūsmām. Šajā pētījumā ğeoloǵiskās vides porainība pieñemta 0,12 .

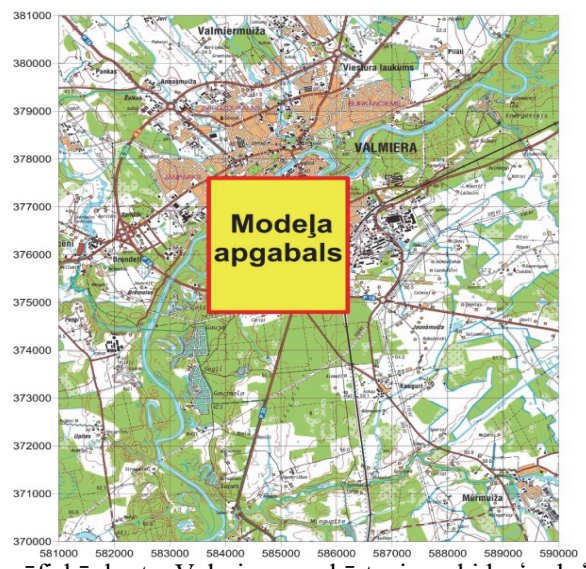

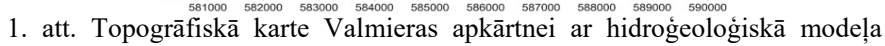
apgabala novietojumu.

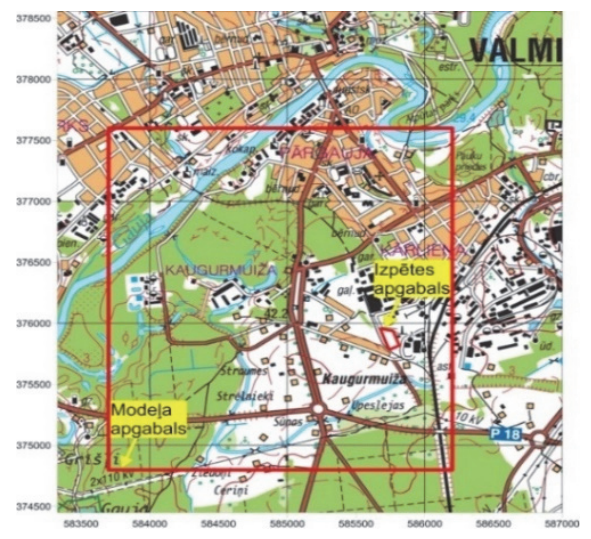

2. att. Hidroǵeoloǵiskā modeḷa topogrāfiskā karte ar izpētes apgabalu. 
Modelēšanas rezultātu vizualizācijai un sākuma datu apstrādei izmantota SURFER 12 un 11 programma [6].

Modeḷa digitālā reljefa karte veidota, izmantojot Latvijas G̣eotelpiskās aǵentūras datus [7].

Bijušās mazuta bāzes piesārņojuma izpētei izmantotais apgabals un urbumu izvietojums skatāms 3. attēlā. Šajā apgabalā VKB speciālisti izveidoja vienpadsmit $U$ tipa urbumus (U1, U2, ..., U11) pazemes ūdens līmen,u un piesārn,ojuma noteikšanai kvartāra ūdens horizontā Q. Trīs DZ tipa urbumi izmantoti pazemes ūdens līmeņa noteikšanai pamatiežu horizontā D2brt. Vienpadsmit G tipa urbumi (G1, $\mathrm{G} 2, \ldots, \mathrm{G} 11)$ izmantoti grunts piesārņojuma noteikšanai. Četros apgabalos - A1, A2, A3, A4 - veikta augsnes (līdz $0,5 \mathrm{~m}$ dziḷumam) piesārn,ojuma noteikšana.

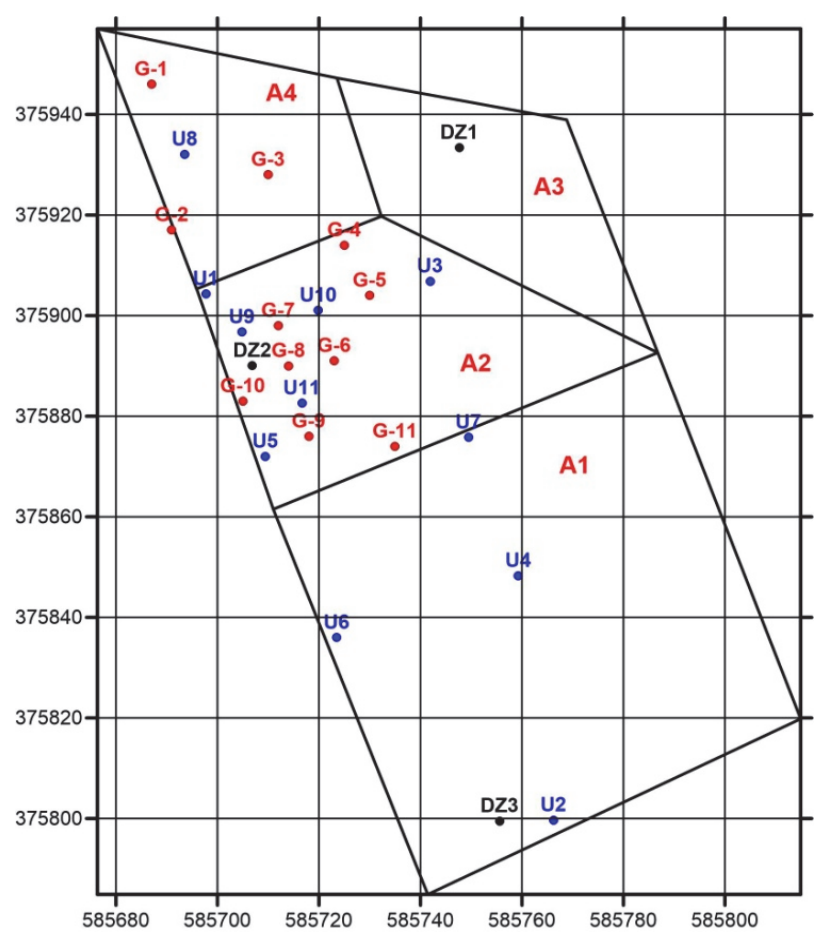

3. att. Izpētes apgabals ar urbumu U, G, DZ izvietojumu un apgabaliem A1, A2, A3, A4.

Vidējais U tipa urbumu dziļums ir 6 metri, un tajos līdz 4 metru dziḷumam noteikts grunts piesārņojums; G tipa urbumu dziḷums ir 4 metri.

Grunts un ūdens paraugiem veiktas BTEX, naftas produktu un metālu analīzes, tāpat gruntīm veiktas granulometriskā sastāva, filtrācijas koeficienta, minerālo dalịnu blīvuma, organisko vielu un citas analīzes [9].

Informācija par pazemes ūdens un grunts piesārnojumu ir apkopota VKB pārskatos [8], [9].

Raksts veltīts bijušās mazuta bāzes teritorijas pazemes ūdens piesārņojuma datormodelēšanas metodikas izklāstam un iegūto rezultātu skaidrojumam.

Piesārņojums pazemes ūdens plūsmā sasniedz Gaujas upi 60 gados. Pirmo 15 gadu laikā tas, pārvietojoties mālsmiltī, pārvar tikai 40 metrus. Tāpēc mazā pazemes ūdens plūsmas ātruma dēl bāzes piesārņojuma izplūdes intensitāte ir niecīga. Pat tad, ja piesārņojums šajā mazuta bāzē daudzkārt pārsniegtu šobrīd novēroto, tas neradītu jūtamu kaitējumu Gaujas upei.
I TABULA

PIESĀRṆOTĀS TERITORIJAS HIDROG̣EOLOG̣ISKĀ MODEḶA SHEMATIZĀCIJA

\begin{tabular}{|c|c|c|c|c|c|}
\hline $\begin{array}{l}\text { HM } \\
\text { slāṇa } \\
\text { Nr. }\end{array}$ & $\begin{array}{c}\text { Slāņa } \\
\text { nosaukums }\end{array}$ & $\begin{array}{l}\text { Slāņa } \\
\text { kods }\end{array}$ & $\begin{array}{c}\text { Filtrācijas } \\
\text { koeficients, } \\
\text { m/dnn } \\
\end{array}$ & $\begin{array}{c}\text { Slāņa } \\
\text { biezums, m }\end{array}$ & Piezīmes \\
\hline 1. & Reljefs & Rel & 10,00 & 0,02 & $\begin{array}{l}\text { Digitālais reljefs } \\
k \bar{k}\end{array}$ \\
\hline 2. & $\begin{array}{c}\text { Aerācijas } \\
\text { zona }\end{array}$ & Aer & $2 \cdot 10^{-3} \cdot(*)$ & $0,50-13,90$ & Sprostslānis \\
\hline 3. & Kvartārs & Q3 & 0,30 un 3,00 & $0,08-5,75$ & $\begin{array}{c}\text { Pieslēgts } \\
\text { Kaugurmuižas } \\
\text { strauts; } \\
\text { Gaujas palienē } \\
k=3,0 \mathrm{~m} / \mathrm{dnn}\end{array}$ \\
\hline 4. & Kvartārs & Q2 & 0,30 un 3,00 & $0,10-7,19$ & $\begin{array}{l}\text { Gaujas palienē } \\
k=3,0 \mathrm{~m} / \mathrm{dnn}\end{array}$ \\
\hline 5. & Kvartārs & Q1 & 0,30 un 3,00 & $0,10-7,19$ & $\begin{array}{c}\text { Pieslēgta } \\
\text { Gauja; } \\
\text { Gaujas palienē } \\
k=3,0 \mathrm{~m} / \mathrm{dnn}\end{array}$ \\
\hline 6. & $\begin{array}{l}\text { Kvartāra } \\
\text { morēna } \\
\text { vai } \\
\text { Burtnieku } \\
\text { alerolīti }\end{array}$ & $\mathrm{gQ}$ & $1,5 \cdot 10^{-4}$ & $0,02-4,81$ & Sprostslānis \\
\hline 7 & Burtnieku & D2brt3 & $1,25-3,00$ & $15,46-17,79$ & $\begin{array}{c}\text { Pieslēgta } \\
\text { Gauja; } \\
\text { Gaujas palienē } \\
k=3,0 \mathrm{~m} / \mathrm{dnn} \\
\end{array}$ \\
\hline 8. & Burtnieku & D2brt2 & $1,25-1,64$ & $15,46-17,79$ & \\
\hline 9. & Burtnieku & D2brt1 & $1,25-1,64$ & $30,92-35,58$ & \\
\hline 10. & Arukilas & D2arz & $2 \cdot 10^{-3}$ & $25,18-26,95$ & Sprostslānis \\
\hline 11. & Arukilas & D2ar & 10,00 & 0,02 & $\begin{array}{c}\text { D2ar } \\
\text { pjezometriskie } \\
\text { ūdens līmeņi kā } \\
\text { robežnoteikums }\end{array}$ \\
\hline \multicolumn{6}{|c|}{$*-\left(10^{-3}-3,3\right)$} \\
\hline
\end{tabular}

\section{HIDROG̣EOLOG̣ISKĀ MODEḶA UZBŪVE}

Valmieras piesārņotās teritorijas HM ir stacionārs, t. i., apraksta vidējos hidroǵeoloǵiskos apstākḷus pamatiežu horizontos D2brt un D2ar un stāvokli ūdens horizontā Q 2017. gada vasarā.

Modelis aproksimē ǵeoloǵisko vidi ar telpisku 3D režǵi, kuru veido $h \times h \times m$ izmēra paralelipedi ( $h$ režğa plaknes solis $10 \mathrm{~m}$; $m$ - mainīgs ǵeologisiskā slāņa biezums), kuru centros atrodas režǵa mezgli.

Modeḷa vertikālā shematizācija skatāma 1. tabulā. Tā ietver 11 režğa plaknes ar izmēru $(250 \times 280)$ mezgli. Šīs plaknes modelē ǵeoloǵiskos slān,us. Kopīgais mezglu skaits modẹ̣a $3 \mathrm{D}$ režǵ í ir $11 \times 250 \times 280=770000$.

MODPATH atrisina algebrisku vienādojumu sistēmu [10]:

$$
A \boldsymbol{\varphi}=\boldsymbol{\beta}-G \boldsymbol{\psi}
$$

kur $\boldsymbol{\varphi}$ - atrisinājuma vektors ir pjezometriskais pazemes ūdens līmenis 3D režğa mezglos;

$A$ - geolog̣iskās vides ūdensvadāmību matrica, kuras elementu vērtības nosaka ǵeologisko slāṇu biezums (iegūts no virsmu $z$ kartēm) un filtrācijas īpašības ( $k$ kartes);

$\boldsymbol{\beta}$ - pazemes ūdens plūsmu robežnoteikumu vektors;

$\boldsymbol{\psi}$ - pazemes ūdens līmeṇu robežnoteikumu vektors; 
$G$ - matrica, kura ievēro $\psi$ tipa noteikumu saites ar ǵeoloǵisko vidi.

Ja ir sagatavotas $z$ un $k$ kartes, kā arī dati par $\boldsymbol{\beta}$ un $\boldsymbol{\psi}$ robežnoteikumiem, tad $G V$ automātiski izveido HM $M O D F L O W$ vidē [2].

Modelī Valmierai neizmanto $\boldsymbol{\beta}$ tipa noteikumus tāpēc, ka pazemes ūdens plūsmu noteikšana dabā ir l,oti problemātiska. Piemēram, infiltrāciju horizontam Q parasti iesaka modelēt kā $\boldsymbol{\beta}$ plūsmu [3], taču tās sadalījums nav zināms, tāpēc tas jāatrod modelētājam. Ar̄̄ LAMO4 $\boldsymbol{\beta}$ noteikumus izmanto tikai ekspluatācijas urbumu ražības modelēšanai.

LAMO4 un arī lokālajā HM Valmierai izmanto $\psi$ noteikumus, jo to vērtības var droši noteikt. No 1. tabulas redzams, ka modeḷa pirmo un vienpadsmito slāni izmanto $\boldsymbol{\psi}$ noteikumu uzdošanai, attiecīgi reljefa un horizonta D2ar pazemes ūdens līmeṇu $\boldsymbol{\psi}$ karšu veidā. Arī Gaujas upes un Kaugurmuižas strauta līmeni ir $\psi$ noteikumi.

Kā $G$ matricas elementi kalpo otrais un desmitais slānis (Aer un D2arz), kas ir sprostslāņi; $G$ matricā arī ietilpst elementi, kas saista upi un strautu ar HM režǵi.

Lai pareizāk modelētu piesārn,ojuma migrāciju, horizonti Q un D2brt ir sadalīti trīs slāṇos.

Aprēḳinātie pazemes ūdens līmeņu sadalījumi ( $\varphi$ kartes) skatāmi pielikuma 3. a attēlā. Pirmā slāņa Rel kartē ietonēta Gaujas upes paliene, kurā Burtnieku smilšakmenuu gultne aizpildīta ar kvartāra aluviālajiem nogulumiem (model̄i slān,i Q un D2brt3). Š̀i iemesla dēl palienes laukumā slāṇu Q3, Q2, Q1 un D2brt3 filtrācijas $k$ kartēs fiksēts $k=3,0 \mathrm{~m} / \mathrm{dnn}$ (skat. 1. tabulu). Šì vērtība būtiski atškiras no mālsmilts $k=0,3 \mathrm{~m} / \mathrm{dnn}$ horizontā Q [8].

Q horizontam $\varphi$ kartes liecina par Kaugurmuižas strauta būtisko ietekmi apgabalā, kurā eksistē sprostslānis gQ. Slāṇa nulles biezuma apgabals ir redzams 3. attēlā.

Horizontam D2brt izmantota LAMO4 $k$ karte.

Pārskatā [8] gruntsūdeṇu plūsma tika prognozēta uz dienvidiem. Tas norāda uz piesārņojuma ieplūdi $200 \mathrm{~m}$ attālumā esošajā strautā. Veicot papildu izpēti 2017. gada jūnijā [9], iegūtie pazemes ūdens līmeṇu mērījumi liecināja par gruntsūdeṇu plūsmu uz ZR. Kā redzams $\varphi$ kartē, pazemes ūdens no bāzes teritorijas plūst uz Gaujas upi.
Var konstatēt, ka $\boldsymbol{\varphi}$ kartes horizontam Q un D2brt ir praktiski identiskas apgabalā, kurā nav sprostslāṇa gQ.

Ūdens plūsmas ātrums horizontā D2ar ir ievērojami mazāks nekā D2brt horizontā. Par to liecina atšķirīgās $\varphi$ kartes šiem horizontiem. Atškirīibas izsauc sprostslānis D2arz.

Infiltrācijas plūsmu sadalījumi ( $q$ kartes $)$ skatāmas Pielikuma 4. a attēlā.

Q3 slāņa $q$ karte parāda, ka infiltrācijas plūsmas $q_{3}$ sadalījums HM augšējā daḷā ir l,oti komplicēts. Modelī tas ir aprēkināts automātiski kā plūsma $q_{\text {Aer }}$ sprostslānī Aer:

$$
q_{\mathrm{Aer}}=q_{3}=g_{\mathrm{Aer}}\left(\boldsymbol{\psi}_{\mathrm{Rel}}-\boldsymbol{\varphi}_{Q 3}\right),
$$

kur $\psi_{\text {Rel }}, \varphi_{\mathrm{Q} 3}-$ ūdens līmeņi model̦a pirmajā un trešajā slānī; $g_{\text {Aer }}-$ sprostslāņa Aer ūdens vadāmība.

Formulu (2) HM var īstenot tāpēc, ka reljefa karte ir izmantota kā $\psi$ tipa robežnoteikums. Plūsmas $q_{3}$ kalibrēšanu veic, mainot $k_{\text {Aer }}$ karti (skat.sadaḷu par HM kalibrēšanu) [10].

Nav ticams, ka modelētājs var sagatavot sarežǵīto plūsmu $\boldsymbol{\beta}_{3}=q_{3}$ kā robežnoteikumu. Tāpēc $\boldsymbol{\psi}_{\text {Rel kartes izmantošana }}$ atbrīvo no tik grūta uzdevuma risināšanas, kā arī būtiski palielina modelēšanas rezultāta ticamību.

No $q$ karšu salīdzinājuma slāṇiem Q3, D2brt3, D2brt2, D2ar var konstatēt, ka, palielinoties to dziḷumam, samazinās pozitīvas infiltrācijas plūsmas ietekme. Piemēram, tikai horizonta D2ar dienvidu-austrumu stūrī eksistē maza pozitīvā plūsma (0-40 mm/gadā). Infiltrācija mazuta bāzes apgabalā samazinās, palielinoties horizontu dzilumam: Q3 = $120 \mathrm{~mm} /$ gadā; D2brt3 $80 \mathrm{~mm} /$ gadā; D2brt2 40 mm/gadā; D2ar $<0$ mm/gadā. D2brt3 slāṇa $q$ kartēs skatāmi infiltrācijas plūsmu kropḷojumi uz slāṇa gQ robežas. Tie neietekmē piesārnojuma kustības modelēšanas rezultātu.

Modeḷa pazemes plūsmu bilanci $\left[\mathrm{m}^{3} / \mathrm{dnn}\right]$ var iegūt, izmantojot $G V$ rīku Mass balance. Rezultāts skatāms 2. tabulā. Bilance sastādīta ūdens slāniiem, ievērojot ieplūdes un izplūdes plūsmas slāṇu augšpusē un apakšā. Modelī kopumā ieplūst $6121,60 \mathrm{~m}^{3} / \mathrm{dnn}$, no tiem 1948,54 $\mathrm{m}^{3} / \mathrm{dnn}$ kā rezultējošā atmosfēras infiltrācija $1948,54=(2118,68-170,14) \mathrm{m}^{3} / \mathrm{dnn}$ un $4172,41=(4183,96-11,55) \mathrm{m}^{3} / \mathrm{dnn}$ no slāṇa D2ar.

II TABULA

HidROG̣EOLOG̣ISKĀ MODEḶA PAZEMES PLŪSMU BILANCE [M³/DNN]

\begin{tabular}{|c|c|c|c|c|c|c|c|c|c|}
\hline \multirow{2}{*}{ Slāṇa kods } & \multicolumn{3}{|c|}{ Slāņa augša } & \multicolumn{3}{|c|}{ Slāņa apakša } & \multirow{2}{*}{$\begin{array}{r}\text { Kopā } \\
4+7\end{array}$} & \multirow{2}{*}{$\begin{array}{l}\text { Caur } \\
\text { robežu }\end{array}$} & \multirow{2}{*}{$\begin{array}{l}\text { Upes, } \\
\text { grāvji }\end{array}$} \\
\hline & Ieplūde & Izplūde & $2+3$ & Ieplūde & Izplūde & $5+6$ & & & \\
\hline 1 & 2 & 3 & 4 & 5 & 6 & 7 & 8 & 9 & 10 \\
\hline Q3 & 2118,68 & $-170,14$ & 1948,54 & 347,72 & $-2078,45$ & $-1730,73$ & 217,79 & 0,10 & $-217,89$ \\
\hline Q2 & 2078,45 & $-347,72$ & 1730,73 & 371,23 & $-2095,37$ & $-1724,14$ & 6,60 & $-6,60$ & 0,00 \\
\hline Q1 & 2095,37 & $-371,23$ & 1724,14 & 551,07 & $-1658,27$ & $-1107,20$ & 616,94 & $-8,17$ & $-608,77$ \\
\hline D2brt3 & 1658,27 & $-551,07$ & 1107,20 & 4545,57 & $-735,34$ & 3810,23 & 4917,43 & $-230,07$ & $-4687,36$ \\
\hline D2brt2 & 735,34 & $-4545,57$ & $-3810,23$ & 4054,40 & $-257,37$ & 3797,03 & $-13,20$ & 13,20 & 0,00 \\
\hline D2brt1 & 257,37 & $-4054,40$ & $-3797,03$ & 4183,96 & $-11,55$ & 4172,41 & 375,39 & $-375,39$ & 0,00 \\
\hline Modelis & 2118,68 & $-170,14$ & 1948,54 & 4183,96 & $-11,55$ & 4172,41 & 6120,97 & $-606,95$ & $-5514,02$ \\
\hline
\end{tabular}


Komponentes $170,14 \mathrm{~m}^{3} / \mathrm{dnn}$ un $11,55 \mathrm{~m}^{3} / \mathrm{dnn}$ ievēro augšupejošo (negatīvo) plūsmu slānī Q3 un nelielo pozitīvo plūsmu horizontā D2ar (skat. 2. a attēlā $q$ kartes slānos Q3 un D2ar). Rezultējošā atmosfēras nokrišnu infiltrācija model̄i ir $101,6 \mathrm{~mm} / \operatorname{gad} \overline{\mathrm{a}}=(0,365 \cdot 1948,54) /(2,5 \cdot 2,8)$.

Kopīgā pazemes pietece upēs ir $5514,02 \mathrm{~m}^{3} / \mathrm{dnn}$, no tiem $217,89 \mathrm{~m}^{3} / \mathrm{dnn}$ Kaugurmuižas strautā, 608,77 m³/dnn Gaujā, horizontā Q1, un 4687,36 m³/dnn Gaujā, slānī D2brt3. Caur HM apgabala robežu aizplūst $606,95 \mathrm{~m}^{3} / \mathrm{dnn}$.

Modeḷa pazemes plūsmu bilance un 4. a attēla $q$ kartes liecina, ka horizontam D2ar ir izškiroša nozīme ticamu rezultātu iegūšanai, īpaši piesārņojuma masas transporta modelēšanā.

\section{HIDROG̣EOLOG̣ISKĀ MODEḶA IZVEIDOŠANA UN KALIBRĒŠANA}

HM Valmierai iegūts, veidojot to no jauna. Pēc hidroǵeologiskās izpētes rezultātā iegūtajiem datiem tika izvēlēta HM shematizācija (skat. 1. tabulu). HM veidošanai izmantoti šādi dati:

- detalizēta zemes reljefa virsmas karte ar plaknes soli $10 \mathrm{~m}$;

- izveidotie Kaugurmuižas strauta un Gaujas piesaistes faili HM;

- sprostslān,u slāņu virsmas un gQ biezums no LAMO4, kas iegūts, izmantojot $G V$ procedūru "Telescopic mesh refinement". Tādējādi no LAMO4 iegūts lokāls HM ar vajadzīgo novietojumu, izmēru un plaknes soli $h$, kas izmantots jaunizveidotajam HM.

HM kalibrēšanai izmantotie izpētes rezultātā iegūtie un Valsts ǵeoloǵijas fonda (VG̣F) dati:

- mazuta bāzes rajonā veiktās hidroǵeoloǵiskās izpētes rezultātā iegūtie dati [9] - pamatiežu virsmas augstums ir $\sim 32 \mathrm{~m}$ vjl. Līdz ar to kvartāra smilšu horizonts $Q$ bāzes teritorijā sasniedz $16 \mathrm{~m}$ biezumu. 2017. gada augustā ar ūdeni piesātinātais horizonta Q biezums $\mathrm{mQ}=14 \mathrm{~m}$ un aerācijas zonas Aer biezums mAer $=$ $2 \mathrm{~m}$;

- Gaujas upes palienē laika gaitā ir izveidojies smilšu sanesums, kurš atrodas slān,os Q3, Q2, Q1, D2brt3 [11];

- datus par pazemes ūdens piesārņojumu var attiecināt tikai uz $4 \mathrm{~m}$ biezu slāni Q3 bāzes teritorijā ( $U$ tipa izpētes urbumu dziḷums $\sim 6 \mathrm{~m}, m_{\text {Aer }}=2 \mathrm{~m}$ );

- pazemes ūdens līmeñiem izpētes urbuma U11 tuvumā slāņos Q3 un D3brt3 ir jābūt 46,0 m vjl un 43,5 m vjl.

Lokālā HM kalibrāciju uzsāk ar slāṇu virsmu ( $z$ kartes) izveidošanu. Sistēmā GV tikai pirmajam slānim Rel ir augšējā un apakšējā virsma $z_{0}$ un $z_{1}$ (top 1 un bot 1). Pārējiem $i$-tiem slān,iem uzdod to apakšas virsmas $z_{i}$ (bot $i$ ). Pirmā slāņa $z_{0}$ ir digitālais reljefs; $z_{1}=\left(z_{0}-0,02\right) \mathrm{m}$ vjl., jo pirmā slāṇa biezums ir $0,02 \mathrm{~m}$.

No LAMO4 ņemtas virsmas $z_{9}$ un $z_{10}$ (sprostslāṇa D2arz virsmas $)$; virsma $z_{11}=\left(z_{10}-0,02\right) \mathrm{m}$ vjl. dod $m_{\mathrm{D} 2 \mathrm{ar}}=0,02 \mathrm{~m}$

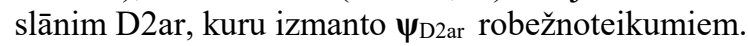

Analizējot LVG̣MC urbumu datu bāzes un pārskata [9] datus, tika izveidota virsma $z_{5}$ slānim Q1. Ar LAMO4 datiem par morēnas gQ biezumu $m_{\mathrm{gQ}}$, bija iespējams izveidot virsmu $z_{6}=\left(z_{5}-m_{\mathrm{gQ}}\right) \mathrm{m}$ vjl.

Burtnieku horizonts ir sadalīts trīs slān,os, kuru biezumi ir $m_{\mathrm{D} 2 \mathrm{brt3}}=m_{\mathrm{D} 2 \mathrm{brt} 2} ; m_{\mathrm{D} 2 \mathrm{brt} 1}=m_{\mathrm{D} 2 \mathrm{brt3}}+m_{\mathrm{D} 2 \mathrm{brt} 2}$. Var izveidot $z_{8}=0,5\left(z_{6}+z_{9}\right) ; z_{7}=0,5\left(z_{6}+z_{8}\right)$.

Virsma $z_{2}$, kas nosaka reālo aerācijas zonas Aer biezumu $m_{\text {Aer}}$, nav zināma. To atrod, īstenojot divus eksperimentus.

Pirmajā eksperimentā $z_{2}=\left(z_{1}-0,46\right) \mathrm{m}$ vjl.; $m_{\mathrm{Q} 1}=m_{\mathrm{Q} 2}=$ $0,02 \mathrm{~m}$, t. i., izmanto $m_{\mathrm{Aer}}=0,5 \mathrm{~m}$. Atbilstoši raksta [12] ieteikumam, $k$ karti aerācijas zonai meklē kā faktoru reizinājumu:

$$
k=k_{1} \cdot k_{2} \cdot k_{3} \cdot k_{4}
$$

kur $k_{1}$ ir ārējā konstante, kuras vērtību nosaka, HM kalibrējot; $k_{2}, \quad k_{3}$ un $k_{4}$ ir lokālo izmainu, slāņu ǵeometrijas un infiltrācijas plūsmu korekcijas faktori. Pirmajā eksperimentā izmanto $k_{2}=1,0$ un 0,$001 ; k_{3}=k_{4}=1,0$. Faktora $k_{2}$ vērtība 0,001 atbilst vietām, kurās ir Gaujas upe un Kaugurmuižas strauts. Faktors samazina virszemes ūdens objektu saiti ar $\boldsymbol{\psi}_{\text {Rel }}$.

Pirmā eksperimenta mērḳis ir atrast $k_{1}$ zonai Aer un $k_{\mathrm{gQ}}$ un $k_{\mathrm{D} 2 \text { arz }}$ sprostslān,iem gQ un D2brtz, lai urbuma U11 tuvumā $\varphi_{\mathrm{Q} 3}=46,0 \mathrm{~m}$ vjl., $\varphi_{\mathrm{D} 2 \mathrm{brt}}=43,5 \mathrm{~m}$ vjl. No 1 . tabulas seko, $\mathrm{ka}$ šo noteikumu nodrošina $k_{1}=2 \cdot 10^{-3} \mathrm{~m} / \mathrm{dnn}, k_{\mathrm{gQ}}=1,5 \cdot 10^{-4}$ $\mathrm{m} / \mathrm{dnn}, k_{\mathrm{D} 2 \mathrm{arz}}=2 \cdot 10^{-3} \mathrm{~m} / \mathrm{dnn}$.

Otrajā eksperimentā atrod faktisko $m_{\text {Aer }}$ un $z_{2}=z_{1}-m_{\text {Aer }}$ :

$$
\begin{aligned}
& m_{\mathrm{Aer}}=\boldsymbol{\psi}_{\mathrm{Rel}}-\boldsymbol{\varphi}_{\mathrm{Q} 3}, \text { ja } q_{3}>0 ; \\
& m_{\mathrm{Aer}}=0,46, \text { ja } q_{3}<0 ; \\
& k_{3}=m_{\text {Aer }} / 0,46 .
\end{aligned}
$$

Īstenojot ǵeometrisko pārveidojumu (4), jānovērš negatīvu $m_{\mathrm{Q}}$ biezumu parādīšanās, ja $m_{\mathrm{Q} 2}=m_{\mathrm{Q} 1}=0,02 \mathrm{~m}$. Faktora $k_{3}$ izmantošana rada stāvokli, kurā ir atrasts faktiskais $m_{\text {Aer, }}$ samazinot slāṇa Q3 ar ūdeni piesātināto biezumu. Infiltrācijas plūsma $q_{\text {Aer }}$ nav izmainīta.

Pēc pirmā un otrā eksperimenta veikšanas urbuma U11 tuvumā $m_{\mathrm{Q}}=14 \mathrm{~m}$. Šeit slāṇu Q3, Q2, Q1 biezumiem jābūt $m_{\mathrm{Q} 3}=4 \mathrm{~m} ; m_{\mathrm{Q} 2}=m_{\mathrm{Q} 1}=5 \mathrm{~m}$, jo dati par piesārn,ojumu urbumos ir iegūti $4 \mathrm{~m}$ dziḷumā (skat. 1. a att.).

Lai nodrošinātu šo noteikumu, ir jāizmanto izmainītais $m_{\mathrm{Q}}=m_{\mathrm{Q} 3}+0,04$ :

$$
m_{\mathrm{Q}}=z_{2}-z_{5} ; z_{3}=z_{2}-2 m_{\mathrm{Q}} / 7 ; z_{4}=0,5\left(z_{3}+z_{5}\right) .
$$

Modeḷa kalibrāciju noslēdz infiltrācijas plūsmas $q_{3}$ korekcijas faktora $k_{4}$ aprēķināšana:

$$
\begin{aligned}
& k_{4}=(2,5 / \Delta \varphi)^{0,9}, \text { ja } \Delta \varphi=\left(\psi_{\mathrm{Rel}}-\varphi_{\mathrm{Q} 3}\right)>2,5 ; \\
& k_{4}=1, \text { ja } \Delta \varphi<2,5 .
\end{aligned}
$$

Faktors $k_{4}$ modelī novērš pārāk lielas, dabā neiespējamas infiltrācijas plūsmas. Piemēram, pirms pārveidojuma (7) infiltrācija slānī Q3 pārsniedza 700 mm/gadā. 


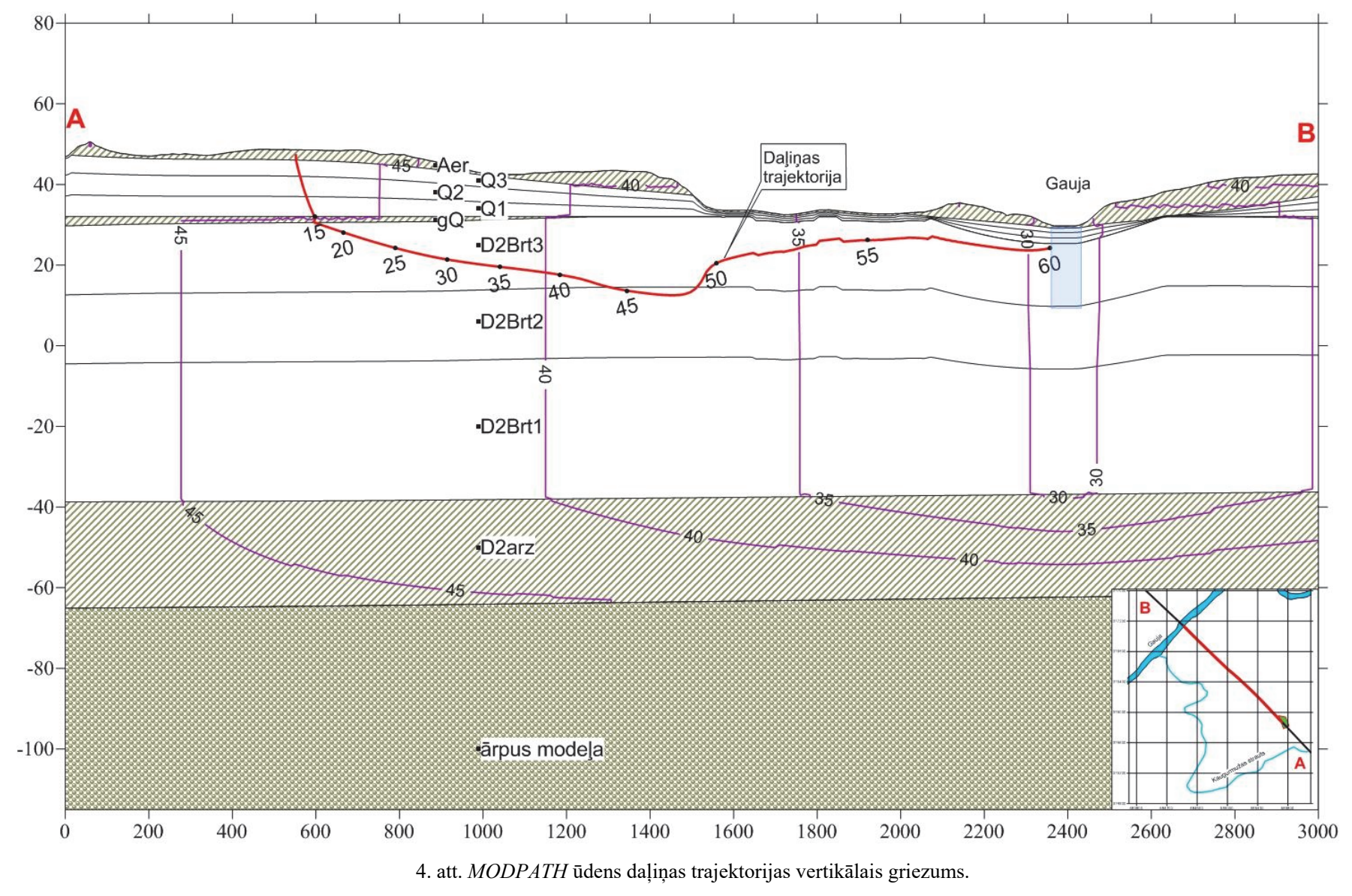

\section{PROGRAMMAS MODPATH IZMANTOŠANA PIESĀRṆOJUMA KUSTĪBAS PĒTĪŠANAI}

Programma MODPATH aprēķina ūdens daļiņas kustību telpā un laikā. MODPATH darbojas HM vidē, kuru izveido MODFLOW programma. Ja ir jāpēta ūden̄i izškīīuša piesārņojuma kustība, MODPATH izmantošana dod l̦oti būtisku informāciju.

Ūdens dalinu ievieto urbumā U11 slānī Q3, piesārṇojuma centrā. Dalinas trajektorija ir skatāma 4. attēlā:

- pirmajos 15 gados dalịna sasniedz D2brt3 slāni. Dalinanas ceḷa garums ir $40 \mathrm{~m}$; vidējais kustības ātrums $v$ ir $\sim 2,5 \mathrm{~m} /$ gadā. Var prognozēt, ka mazā pazemes plūsmas ātruma dēḷ bāzes piesārṇojuma izplūdes intensitāte būs niecīga;

- slāṇos D2brt3 un D2brt2 dalina pavada 45 gadus, līdz tā sasniedz Gaujas upi. Dalinas ceḷa garums - 1800 m; pēc iekḷūšanas slānī D2brt3, v ir 22 m/gadā; Gaujas upes tuvumā $-v$ ir $\sim 80 \mathrm{~m} / \mathrm{gadā}$;

- apgabalā, kur darbojas augšupejošās (negatīvās) plūsmas (skat. 4. a att.), dalininas trajektorija tuvojas zemes virsmai.

Daḷiņas mazais ātrums horizontā $Q$ ir izskaidrojams galvenokārt ar $k=0,3 \mathrm{~m} / \mathrm{dnn}$ mālsmiltij. Gaujas palienē daḷiņa pārvietojas ātrāk, jo šeit $k=3,0 \mathrm{~m} / \mathrm{dnn}$ (skat. 1. tabulu).

MODPATH nedod informāciju par piesārṇojuma koncentrācijas un masas izmaiṇām laikā un telpā. Tādus datus var iegūt, izmantojot programmu MT3D.

\section{AR PROGRAMMU MT3D IEGŪTIE REZULTĀTI}

Izmantojot programmu $M T 3 D$, veikti skaitliskie eksperimenti, kuros pazemes ūdens piesārṇojums slānī Q3 modelēts, izmantojot relatīvās koncentrācijas $C_{\mathrm{r}}=100 \%$ avotu trīs režğa šūnās, kurām atbilst maksimālās $B T E X$ komponenšu koncentrācijas (skat. Pielikuma 1. a att. un 1. a tabulu). Koncentrāciju $C_{\mathrm{r}}$ un faktiskās koncentrācijas saista vienādojums:

$$
C_{\mathrm{t}}=0,01 C_{\mathrm{r}} \cdot C_{\max }
$$

kur $C_{\mathrm{t}}$ un $C_{\max }$ ir aprēḳinātā laikā main̄̄gā koncentrācija piesārņojuma avotā.

Vispārīgāku, tomēr mazāk uzskatāmu rezultātu varētu iegūt, ja $M T 3 D$ izmantotu sarežğîtāku izkliedētu piesārṇojuma avotu, kuru veidotu režğa šūnas, kurām to koncentrācijai būtu izmantoti 1. a attēla dati.

Par MT3D ieejas datu aprēḳinu skat. Pielikuma iedaḷu "Pazemes ūdens piesārṇojums izpētes apgabalā".

Programma $M T 3 D$ avota koncentrāciju $C_{\mathrm{r}}=100 \%$ izmanto masas $M_{100}$ aprēķinam, kā $\mathrm{C}=100 \mathrm{~kg} / \mathrm{m}^{3}$. Tāpēc masu $M_{100}$, $\mathrm{kg}$, ar faktisko masu $M_{\mathrm{c}}$, ja $C=C_{\max }, \mathrm{mg} / \mathrm{m}^{3}$, saista formula:

$$
M_{\mathrm{c}}, \mathrm{g}=C_{\max } \cdot U ; \quad U=M_{100} \cdot 10^{-5},
$$

kur $U$ ir relatīvā piesārnojuma masa. Bezdimensiju parametrs $U$ (skat. 5. att.) ir $M T 3 D$ aprēkininu rezultāts. 
Īstenoti trīs skaitliskie eksperimenti 100 gadu laikam:

- $\quad$ ievēro tikai ūdens kustību (advekcija);

- $\quad$ papildus ievēro vielas degradāciju ar $t_{0,5}=10$ gadi;

- pirmajā eksperimentā pēc 25 gadiem likvidē piesārņojuma avotu.

Pirmais un otrais eksperiments dod informāciju par piesārṇojuma koncentrācijas un masas izmaiṇu laikā un telpā, ja nelikvidē avotu. Otrajam eksperimentam $t_{0,5}=10$ gadi n,em vērā, ka horizontā D2brt piesārn,ojuma destrukcijas ātrums būs mazāks nekā horizontā Q. Rakstā [15] tam izmanto $t_{0,5}=(2-3)$ gadi. Trešais eksperiments parāda piesārnojuma avota likvidācijas ietekmi.

Izmantota "finite difference" metode; laika solis 73 dienas $=0,2$ gadi. Metode precīzi aprēḳina piesārņojuma masu, taču tai piemīt ievērojama skaitliskā dispersija. Š̄̄ iemesla dēl nav īpaši pētīta dispersijas ietekme uz piesārn,ojuma kustību, jo šo ietekmi demonstrē izmantotā metode.

Relatīvās piesārṇojumu koncentrācijas pēc 25 un 60 gadiem pirmajam eksperimentam slānos Q1 un D2brt3 skatāmas Pielikuma 5a. attēlā.

Var konstatēt, ka augšupejošas plūsmas dēḷ jau pēc 25 gadiem slānī Q1 (arī Q2 un Q3) radies koncentrāciju apgabals, kura austrumu robeža sakrīt ar nulles infiltrācijas līniju (skat. 4a. att.). Koncentrāciju sadalījumi slāṇos Q1 un D2brt3 šajā apgabalā ir identiski, jo šeit neeksistē sprostslānis gQ. Pēc 60 gadiem koncentrāciju sadalījumi slāṇos Q1 un D2brt3 nemainās, jo ir iestājies līdzsvars starp piesārṇojuma ieplūdi upē un izplūdi no bāzes.

Otrajam un trešajam eksperimentam nav parādīti relatīvo koncentrāciju sadalījumi, jo tie principiāli neatšksiras no pirmajā eksperimentā iegūtajiem.

Slāņos Q3, Q2, Q1 un D2brt3 ierīkoti virtuāli monitoringa urbumi 3.1, 4.1, 5.1, 5.2 un 7.1, 7.2, 7.3. Urbumi 3.1, 4.1, 5.1 un 7.1 atrodas tuvu piesārnojuma avotam, urbumi 5.2 un 7.2 novietoti $600 \mathrm{~m}$ attālumā no upes, bet urbums 7.3 ir pie upes. Katram monitoringa urbumam GV sistēma izveido hidrogrāfu, kas parāda relatīvo koncentrāciju izmaiṇu laikā.

Monitoringa urbumu hidrogrāfi skatāmi pielikuma 6. a attēlā. Hidrogrāfi pēc to rakstura un stacionārajām vērtībām sakārtoti trīs grupās: $(3.1,4.1,5.1)$, (7.1) un (7.2, 7.3). Hidrogrāfs 5.2 nav izmantots, jo tas ir identisks hidrogrāfam 7.2. Hidrogrāfu stacionārās vērtības apkopotas III. tabulā.

Pirmās grupas hidrogrāfu stacionārās vērtības, \%, mainās pirmā un otrā eksperimenta robežās no 7,0 līdz 55,0; hidrogrāfam 7.1 - no 0,75 līdz 1,65; trešajā grupā no 0,001 līdz 0,130. Visiem hidrogrāfiem stacionārā vērtība ir nulle trešajā eksperimentā. Pirmās grupas hidrogrāfi stacionāro vērtību sasniedz 10 -15 gados. Palielinoties ǵeologiskā slāṇa dziḷumam, hidrogrāfu izmaiṇas ātrums un stacionārās vērtības samazinās. Otrajā eksperimentā stacionārās vērtības ir tikai nedaudz mazākas nekā pirmajā eksperimentā (skat. 3. tabulu), t. i., piesārņojuma avota tuvumā vielas destrukcija maz ietekmē koncentrāciju sadalījumu.
III TABULA

RELATĪVO KONCENTRĀCIJU, \%, HIDROGRĀFU STACIONĀRĀS VĒRTĪBAS PĒC 100 GADIEM

\begin{tabular}{|c|r|r|r|}
\hline \multirow{2}{*}{$\begin{array}{l}\text { Monitoringa } \\
\text { urbuma Nr. }\end{array}$} & \multicolumn{3}{|c|}{ Eksperimenta numurs } \\
\cline { 2 - 4 } & 1 & 2 & 3 \\
\hline 3.1 & 55,00 & 52,4000 & 0,00 \\
\hline 4.1 & 24,10 & 21,8000 & 0,00 \\
\hline 5.1 & 9,00 & 7,0000 & 0,00 \\
\hline 7.1 & 1,65 & 0,7500 & 0,00 \\
\hline 7.2 & 0,13 & 0,0045 & 0,00 \\
\hline 7.3 & 0,05 & 0,0010 & 0,00 \\
\hline
\end{tabular}

Hidrogrāfa 7.1 stacionārās vērtības 1,65 un 0,75 norāda uz piesārņojuma koncentrācijas samazināšanos slān̄i D2brt3 attiecīgi 60 un 133 reizes pirmajam un otrajam eksperimentam. Hidrogrāfs stacionāro vērtību sasniedz pēc 25 gadiem. Koncentrācijas pirmajam eksperimentam samazinās piesārņojuma atšķaidīšanās dēl, bet otrajā eksperimentā kā papildu faktors darbojas piesārņojuma destrukcija.

Trešās hidrogrāfu grupas stacionārās vērtības pirmajā un otrajā eksperimentā norāda uz līdzsvara iestāšanos starp piesārņojuma avotu izdalīto masu un tās ieplūdi upē un ar̄̄ vielas degradāciju otrajā eksperimentā. Destrukcijas dēl hidrogrāfu 7.2 un 7.3 vērtības attiecīgi samazinās: $0,13 \rightarrow 0,0045$ un $0,05 \rightarrow 0,001$, t. i., 29 un 50 reizes, salīdzinot ar pirmo eksperimentu. Stacionāro vērtību hidrogrāfi sasniedz tikai pēc 70-80 gadiem. Trešajā eksperimentā abu hidrogrāfu vērtību maksimumi gandrīz sasniedz pirmā eksperimenta stacionāros līmeņus (skat. 6. a att.).

Piesānnojuma relatīiās masas izmaiṇas trijiem eksperimentiem skatāmas 5. attēlā. Pirmajam un otrajam eksperimentam piesārṇojuma avota izdalītā masa palielinās lineāri. Trešajā eksperimentā tā aug tikai pirmajos 25 gados.

Pirmajā eksperimentā pēc 60 gadiem notiek procesa stabilizācija līmen̄i $U=4,8$, kad piesārņojuma masas ieplūde upē ir vienāda ar avota izplūdes masu.

Otrajā eksperimentā piesārṇojuma sabrukšanas dēl, jau pēc 20 gadiem notiek procesa stabilizācija līmen̄i $U \sim 1,0$. Ļoti iespējams, ka dabā intensīva naftas produktu degradācija notiek horizontā Q mikroorganismu darbības rezultātā.

Trešajā eksperimentā upes ietekmes dēl, relatīvā masa pēc 60 gadiem samazinās ātrāk. Eksperiments pierāda, ka piesārņojuma avota likvidācija ir obligāts priekšnoteikums vides atveseḷošanai. Tomēr vides pašattīrǐšanās process nav ātrs, jo tam nepieciešami vismaz 75 gadi pēc avota likvidācijas.

Pirmais eksperiments dod maksimālo piesārṇojumu pazemes ūden̄i. Aptuvenais bāzes piesārņojuma vecums ir 60 gadi, kam atbilst $U=4,6$. Izmantojot formulu (9), aprēḳina $B T E X$ masu $M_{\mathrm{c}}=44,32 \times 4,6=203,9$ grami; $C_{\max }=44,32 \mathrm{mg} / \mathrm{m}^{3}$ (skat. IA. tabulu). Piesārņojuma avota izdalītā masa 60 gados ir $44,32 \times 5,7=252,6$ grami $(U=5,7)$. 


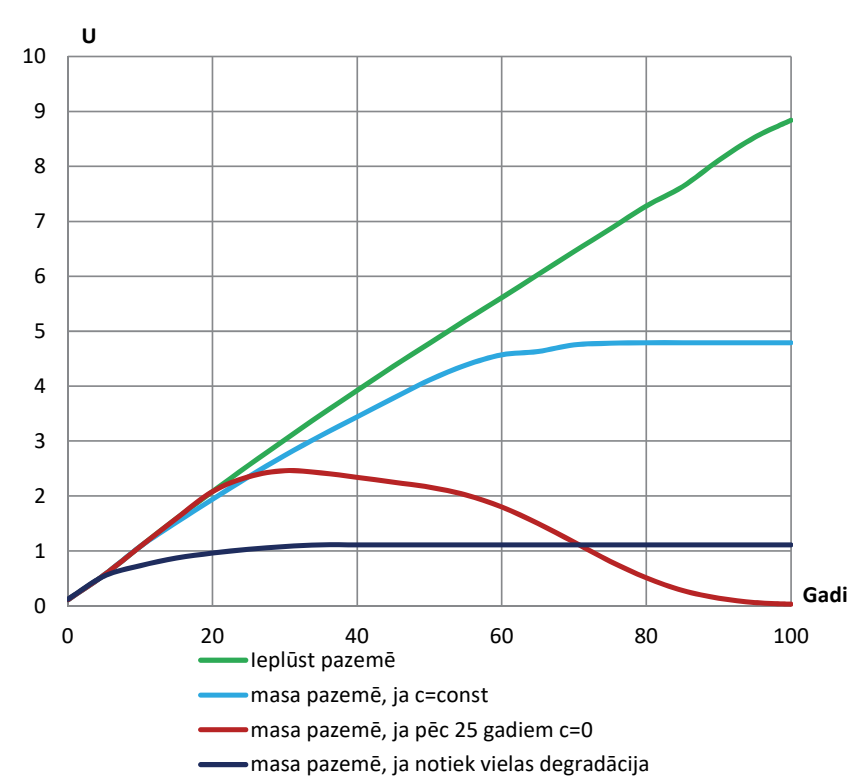

5. att. Relatīvās masas izmaiņas laikā līdz 100 gadiem.

Avota intensitāte ir tikai $0,012 \mathrm{~g} / \mathrm{dnn}=252,6 /(60 \cdot 365)$. Pat ja senāk piesārnojuma koncentrācija pazemes ūdenī bijušajā mazuta bāzē daudzkārt pārsniedza pašreiz novēroto, bāzes piesārņojums nevar ietekmēt Gaujas upi, jo tās rezultējošā pazemes pietece pie Valmieras ir $1200 \cdot 10^{3} \mathrm{~m}^{3} / \mathrm{dnn}$ [16]. Ievērojot virszemes pieteci, upes vidējā gada caurtece pie Valmieras ir vismaz $1200 \cdot 10^{3} \cdot 3=3600 \cdot 10^{3} \mathrm{~m}^{3} / \mathrm{dnn}$.

Ja modeḷa slān̨a Q3 biezums bāzes teritorijā nebūtu $4.0 \mathrm{~m}$, tad ar MT3D programmu iegūtie rezultāti būtu kḷūdaini, jo aprēķina sākuma dati par piesārņojuma avotu nebūtu saskaņoti ar eksperimentāli iegūtajiem datiem par pazemes ūdens piesārṇojumu. Pareizas ǵeologiisko slānnu ǵeometrijas izmantošana ir būtisks noteikums ticamu rezultātu iegūšanai ar $M T 3 D$ programmu.

\section{SECINĀJUMI}

Lai novērtētu Valmieras bijušās mazuta bāzes naftas produktu piesārṇojuma kaitējumu pazemes ūdeṇiem, Valsts SIA "Latvijas Vides, ǵeoloǵijas un meteoroloǵijas centrs" kopā ar Rīgas Tehnisko universitāti izveidoja un izmantoja piesārnotās teritorijas lokālu hidroǵeoloğisko modeli. Modelis izveidots izmantojot hidroǵeologiskās izpētes [8], [9], urbumu datu bāzes, VG̣F un Latvijas hidroǵeologískā modeḷa LAMO4 datus. Modelēšanas rezultāti pārliecina, ka naftas produktu piesārṇojums pazemes ūdeṇu bijušajā bāzē praktiski neietekmē vides kvalitāti. Hidroǵeologiskā un piesārṇojuma masu transporta modeḷa veidošanas un izmantošanas aprakstus var izmantot modelēšanas speciālisti pazemes ūdens piesārņojuma pētīšanas metožu pilnveidošanai.

Lokālais Valmieras hidrog̣eologiskais modelis izveidots projekta "INSURE" (CB Nr. 39) ietvaros.

Latvijas hidroǵeologiskais modelis LAMO4 ir izveidots, īstenojot Valsts pētijumu programmu "EVIDEnT".

\section{LITERATŨRAS SARAKSTS}

[1] A. Spalviňš, "Geological Model of Latvia Developed at Riga Technical University (2010-2015)," Boundary Field Problems and Computer Simulation, vol. 55, pp. 5-11, Dec. 2016.

https://doi.org/10.7250/bfpcs.2016.001
[2] Environmental Simulations, Inc. Groundwater Vistas. Version 6, Guide to using, 2011.

[3] W. Harbaugh, "MODFLOW-2005, U.S. Geological Survey Modular Ground-Water Model: The Ground-Water Flow Process," US Geological Survey Techniques and Methods 6-A16, chap. 16, book 6. Virginia: U.S. Geological Survey, Reston USGS, 2005 [Online]. Available: http://inside.mines.edu/ epoeter/583CSM/DOC4 MODFLOW2005TM6A16.pdf

[4] D. W. Pollok, User's Guide for MODPATH/MODPATH-Plot, Version 3. A Particle Tracking Post-Processing Package for MODFLOW, the US Geological Survey Finite-Difference Groundwater Flow Model, Virginia: U.S. Geological survey, Sep. 1994 [Online]. Available: https://pubs.usgs.gov/of/1994/0464/report.pdf

[5] C. Zheng and P. P. Wang, MT3D99 A Modular Three Dimensional Transport Model for Simulation of Advection, Dispersion and Chemical Reactions of Contaminants in Groundwater Systems. Alabama University, Tuscaloosa, 1999.

[6] Golden Software, Inc., SURFER-12 for Windows, Users manual, Guide to Using, 2015

[7] Latvijas G̣eotelpiskās informācijas aǵentūras digitālie reljefa dati.

[8] P. Birzgalis, Pārskats “ Ar naftas produktiem potenciāli piesārṇotās mazuta saimniecības teritorijas izpētes stratēǵijas izstrāde, ietverot teritorijas topogrāsisku uzmērīšanu Valmierā, Dzelzceḷa ielā 9", SIA Vides konsultāciju birojs, Rīga, 20 lpp., 2016.

[9] P.Birzgalis, Pārskats "Par ǵeoekolog̣iskās izpētes darbiem objektā mazuta bāze Valmierā, Dzelzceḷa ielā 9, SIA Vides konsultāciju birojs, Rīga, 15 lpp., 2017.

[10] A. Spalviņš, J. Šlangens, I. Lāce, K. Krauklis, and O. Aleksāns, "Efficient Methods Used to Create Hydrogeological Model of Latvia," International Rewiew on Modelling and Simulations (I.RE.MO.S), vol. 6, no. 5, Oct. 2013

[11]M. Induḷēvičs, Pārskats par inženierǵeologisko izpēti objektam "Valmieras generālplāns". Rīga: Latgiprogorstroj, VG̣F Inv. Nr. 10293, 1985.

[12]A. Spalviņš, K. Krauklis, and I. Lāce, "G̣eologiisko slāṇu ūdens filtrācijas koeficienta kartes Latvijas hidrog̉eologiskajā modelī," Latvijas Universitātes 75. zinātniskā konference, Starptautiskais simpozijs "Smilts un stikls", Latvijas Universitāte, Zinātnisko rakstu krājums, 21.-30. lpp., 2017.

[13]MK 2002. gada 12. marta noteikumi Nr. 118, "Ūdens kvalitātes normatīvi pazemes ūdeṇu stāvokḷa novērtēšanai un prasības pazemes ūdeṇu attīrī̌sanai piesārnotās vietās".

[14]MK 2005. gada 25. oktobra noteikumi Nr. 804, "Noteikumi par augsnes un grunts kvalitātes normatīviem".

[15]E. R. Weiner, Applications of Environmental Aquatic Chemistry. A Practical guide, CRC Press, p. 400, 2007.

[16]A. Spalvin̄š, J. Slangens, I. Lāce, O. Aleksāns, K. Krauklis, V. Skibelis, and I. Eglite, "The Novel Updates of the Hydrogeological Model of Latvia," Boundary Field Problems and Computer Simulation, vol. 54, p. 23, Dec. 2015. https://doi.org/10.7250/bfpcs.2015.005

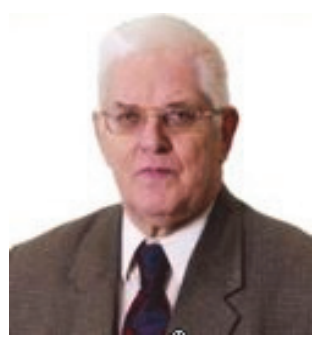

Aivars Spalvin̄š was born in Latvia. In 1963, he graduated from the Riga Polytechnical Institute (since 1990 - Riga Technical University) as a Computer Engineer. A. Spalviňs is the Head of the Environment Modelling Centre of RTU. His research interests include computer modelling of groundwater flows and migration of contaminants.

E-mail: Aivars.Spalvins@rtu.lv

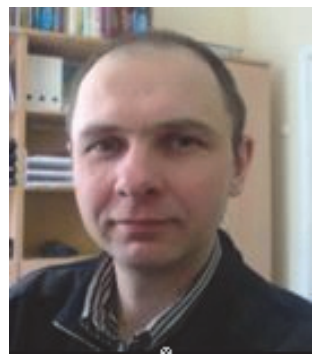

Kaspars Krauklis received the Master's degree in Computer Systems from the Riga Technical University in 2007 and the Certificate in Teaching of Engineering Sciences from the Institute of Humanities of RTU in 2005. He is a researcher at the Environment Modelling Centre of RTU.

E-mail: kasparskrauklis@gmail.com 


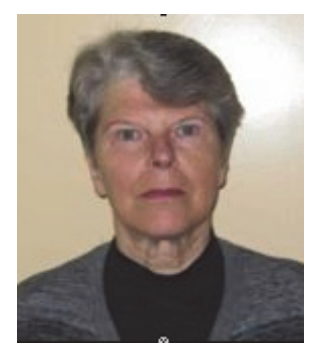

Inta Lāce was born in Latvia. In 1971, she graduated from Riga Polytechnical Institute (since 1990 - RigaTechnicalUniversity) as a Computer Engineer. In 1995, I. Lāce received the Master's degree in Applied Computer Science. Since 1991, she is a researcher at the Environment Modelling Centre of RTU.

E-mail: intalace@yahoo.com

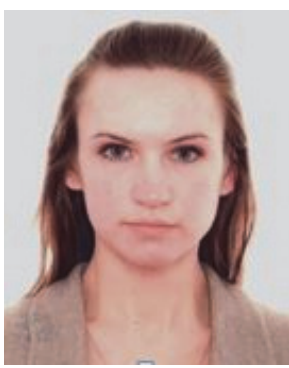

Daiga Pipira graduated from the University of Latvia as a Geologist. In 2015, she received the $\mathrm{PhD}$ in the field of Bedrock Geology. D. Pipira is the Head of the Subsoil Department at the State Ltd. "Latvian Environment, Geology and Meteorology Centre".

E-mail: daiga.pipira@lvgmc.lv

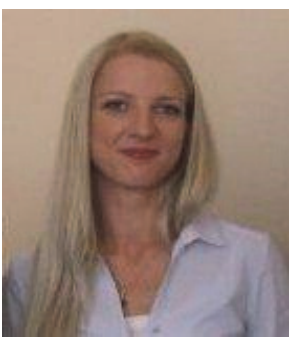

Sandra Karuša received the Master`s degree in Geology from the University of Latvia in 2016 and currently is a PhD student. S. Karuša is a hydrogeologist in the Latvian Environment, Geology and Meteorology Centre (LEGMC) and deals with groundwater modeling, groundwater management issues and subsoil microbiology biodiversity and ecological services.

E-mail: sandra.karusa@lvgmc.lv

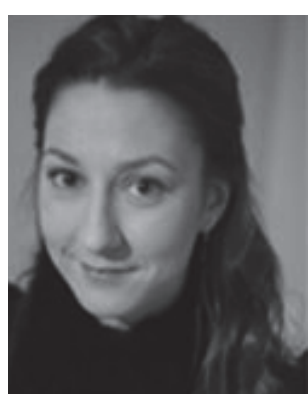

Inga Retike received the Master's degree in Environmental Science from the University of Latvia (UL), Faculty of Geography and Earth Sciences in 2012. Currently she is a $\mathrm{PhD}$ student at the UL and working as a hydrogeology expert in the Latvian Environment, Geology and Meteorology Centre. Main research topics are groundwater status assessment in Latvia according to the European legislation; groundwater hydrochemistry with respect to multivariate statistics and chemistry forecasting tools.

E-mail: inga.retike@lvgmc.lv

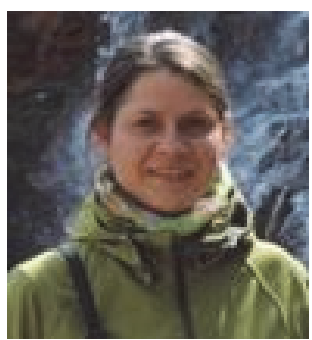

Madara Mame received the Master's degree in Geography from the University of Latvia in 2013. Works as a hydrogeologist in the Latvian Environment, Geology and Meteorology Center since 2016.

E-mail: madara.mame@lvgmc.lv

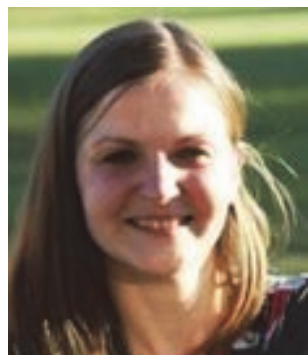

Linda Fībiga received the Master's degree in Heat, Gas and Water Technology from Riga Technical University in 2008. Currently she is working in the Latvian Environment, Geology and Meteorology Centre (LEGMC) dealing with river basin management issues.

E-mail: linda.fibiga@lvgmc.lv

\section{Hydrogeological Modelling of Oil Contaminated Site in Valmiera}

Aivars Spalviṇš ${ }^{1}$, Kaspars Krauklis² ${ }^{2}$ Inta Lāce ${ }^{3}$, Daiga Pipira ${ }^{4}$, Sandra Karuša ${ }^{5}$, Inga Retiḳe ${ }^{6}$, Madara Mame ${ }^{7}$, Linda Fībiga $^{8}$

${ }^{1-3}$ Riga Technical University, Latvia, ${ }^{4-8}$ Latvian Environment, Geology and Meteorology Centre, Latvia

The former black fuel (mazut) storage area in Valmiera is contaminated by oil products. However, until now, no research was done on the evaluation of the contaminated area influence on the quality of groundwater and soil pollution. In 2016-2017, the company "Vides konsultāciju birojs" investigated the area in order to obtain information on the contamination. The Latvian Environment, Geology and Meteorology Centre together with Riga Technical University have developed the local hydrogeological model for the research on the groundwater contamination and its migration in the groundwater flow. The model base was extracted from the hydrogeological model of Latvia (LAMO4). It has been found out that contaminated groundwater may reach the River Gauja in 60 years. During the first 15 years in sandy loam only 40 metres can be covered. The remaining 45 years may be spent to reach the river that is located $1.8 \mathrm{~km}$ from the base. During the first 15 years, due to dilution, the concentration of contaminants drops 60 times. During this time period, intensive contaminant destruction may take place. Results of hydrogeological modelling convince that groundwater contamination has only slight influence on the base area environmental quality.

Descriptions of the building and using the hydrogeological and contaminant transportation models can be useful for modellers dealing with groundwater contamination problems.

Keywords - Contaminated groundwater, hydrogeological model, oil products. 


\section{PIELIKUMS}

\section{A. Pazemes ūdens piesārņojums izpētes apgabalā}

Pazemes ūdeņu piesārņojuma modelēšanai ar $M T 3 D$ programmu bija jāveic BTEX komponenšu $B$ (benzols), $T$ (toluols), $E$ (etilbenzols) un $X$ (ksilolu summa) eksperimentāli iegūto datu [8] apstrāde. Aprēksina apgabalā ar izmēru $36 \mathrm{~m} \times 38 \mathrm{~m}=1368 \mathrm{~m}^{2}$ (skat. 1a. att.) izmantota Kriging interpolācijas metode [7]. Apgabalā iekḷauti urbumi U1, U10, U11, kuros piesārn,ojuma koncentrācija ir lielāka par fonu $0,25 \mathrm{mg} / \mathrm{m}^{3}=0.25 \mu \mathrm{g} / 1 \mathrm{komponentēm} B, T, E$ un $1,0 \mathrm{mg} / \mathrm{m}^{3} X \mathrm{komponentei}$. Fona koncentrāciju uz apgabala perimetru nodrošina palīgurbumi, kuri novietoti $2 \mathrm{~m}$ attālumā viens no otra. IA. tabulā skatāms

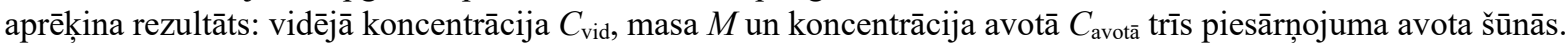

Izmantotās fona koncentrācijas ir tuvas MK noteikumu [13] normatīvajiem mērķlielumiem, $\mu \mathrm{g} / \mathrm{l}: B=0,2 ; T=E=X=0,5$; vidējās koncentrācijas ir būtiski mazākas par robežlielumiem, $\mu \mathrm{g} / \mathrm{l}: B=5 ; T=50 ; E=X=60$.

Kopīgā $B T E X$ masa ir 6.38 grami, un vidējā koncentrācija ir $9,72 \mathrm{mg} / \mathrm{m}^{3}$. Piesārṇojuma avotā fiksēta $C_{\text {avotā }}=44,32 \mathrm{mg} / \mathrm{m}^{3}$. Šo lielumu izmanto $B T E X$ piesārņojuma faktisko koncentrāciju un masas aprēḳinos.

\section{B. Grunts piesārņojums izpētes apgabalā}

Pārskata [8] dati par grunts piesārṇojumu nav izmantoti modelēšanas eksperimentos. Tie ir apstrādāti ar Kriging metodi aprēḳina apgabalā ar izmēru $26 \mathrm{~m} \times 14 \mathrm{~m}=364 \mathrm{~m}^{2}$ (skat. 2a. att.). Apgabalā iekḷauti urbumi G10 un U11, kuru koncentrācijas pārsniedz $25 \mathrm{mg} / \mathrm{kg}$. Fona koncentrāciju uz apgabala perimetru nodrošina palīgurbumi, kuri novietoti $2 \mathrm{~m}$ attālumā viens no otra. IIA. tabulā ir skatāms aprēḳina rezultāts četriem parauga ņemšanas intervāliem: vidējā koncentrācija $C_{\text {vid }}$ un masa $M$. Kopīgā masa $M=6565,5 \mathrm{~kg}$; intervālos: $M_{01}=538,1 \mathrm{~kg}, M_{12}=3639,6 \mathrm{~kg}, M_{23}=2179,8 \mathrm{~kg}$ un $M_{34}=470,3 \mathrm{~kg}$. Naftas produktu summas vidējā koncentrācija visos paraugu ņemšanas intervālos pārsniedz MK noteikumu [14] normatīvu $B=500$ mg/kg; intervālā (1-2) $C_{\text {vid }}$ pārsniedz normatīvu $C=5000 \mathrm{mg} / \mathrm{kg}$.

Nav pārliecības, ka aprēķina rezultāti patiesi atbilst faktiskajam grunts piesārņojumam bijušajā mazuta bāzē, jo rezultātu faktiski nosaka dati tikai vienā urbumā (G10). Kopīga BTEX svara daḷa 8,5 \% intervālā (3-4) nav raksturīga mazutam [15]. Iespējams, ka bāzes teritorijā notikuši citu naftas produktu izlijumi.

IA. TABULA

KOPSAVILKUMS PAR PAZEMES ŪDENS PIESĀRṆOJUMA APRĒḲINU IZPĒTES APGABALĀ

\begin{tabular}{|c|c|c|c|c|c|}
\hline Viela & Benzols & Toluols & Etilbenzols & Ksilols & $B T E X$ \\
\hline 1 & 2 & 3 & 4 & 5 & $2+3+4+5$ \\
\hline$V_{c}$ & 1823,60 & 1013,70 & 1150,40 & 3314,00 & 13301,70 \\
\hline$C_{\text {vid }}, \mathrm{mg} / \mathrm{m}^{3}$ & 1,33 & 0,74 & 0,84 & 6,81 & 9,72 \\
\hline$M, \mathrm{~g}$ & 0,87 & 0,49 & 0,55 & 4,47 & 6,38 \\
\hline$C_{\text {fona }}, \mathrm{mg} / \mathrm{m}^{3}$ & 0,25 & 0,25 & 0,25 & 1,00 & 1,75 \\
\hline$C_{\text {avotāā }}, \mathrm{mg} / \mathrm{m}^{3}$ (trīs šūnās) & 6,07 & 3,37 & 3,83 & 31,05 & 44,32 \\
\hline
\end{tabular}

IIA. TABULA

KOPSAVILKUMS PAR NAFTAS PRODUKTU KONCENTRĀCIJU UN MASU GRUNTĪ ČETROS PARAUGU N̦EMŠANAS INTERVĀLOS (0-1) M, (1-2) M, (2-3) M, (3-4) M

\begin{tabular}{|c|c|c|c|c|c|}
\hline Intervāls & $0-1$ & $1-2$ & $2-3$ & $3-4$ & Kopā \\
\hline 1 & 2 & 3 & 4 & 5 & $2+3+4+5$ \\
\hline$V_{c}$ & 195874,0 & 2584895,0 & 1548129,0 & 333996,0 & 4662894,0 \\
\hline$C_{\text {vid }}, \mathrm{mg} / \mathrm{kg}$ & 538,1 & 7101,4 & 4253,1 & 917,6 & 12810,2 \\
\hline$M, \mathrm{~kg}$ & 275,8 & 3639,6 & 2179,8 & 470,3 & 6565,5 \\
\hline$C_{\text {fona }}, \mathrm{mg} / \mathrm{m}^{3}$ & 25,0 & 25,0 & 25,0 & 25,0 & 100,0 \\
\hline \multicolumn{6}{|c|}{$\begin{array}{l}\text { Aprēḳina laukums }-364 \mathrm{~m}^{2} \text {; grunts intervāla biezums }-1 \mathrm{~m} \text {; porainība }-0,12 \text {; grunts blīvums }-1,6 \text {; } \\
C_{\text {vid }}, \mathrm{mg} / \mathrm{kg}=V_{c} / 364 ; V_{c}-\text { "Kriging tilpums" (skat. 2a. att.); } M, \mathrm{~kg},=364 \cdot 1 \cdot 0,88 \cdot 1600 \cdot 10^{-6} \cdot C_{\text {vid }}\end{array}$} \\
\hline
\end{tabular}



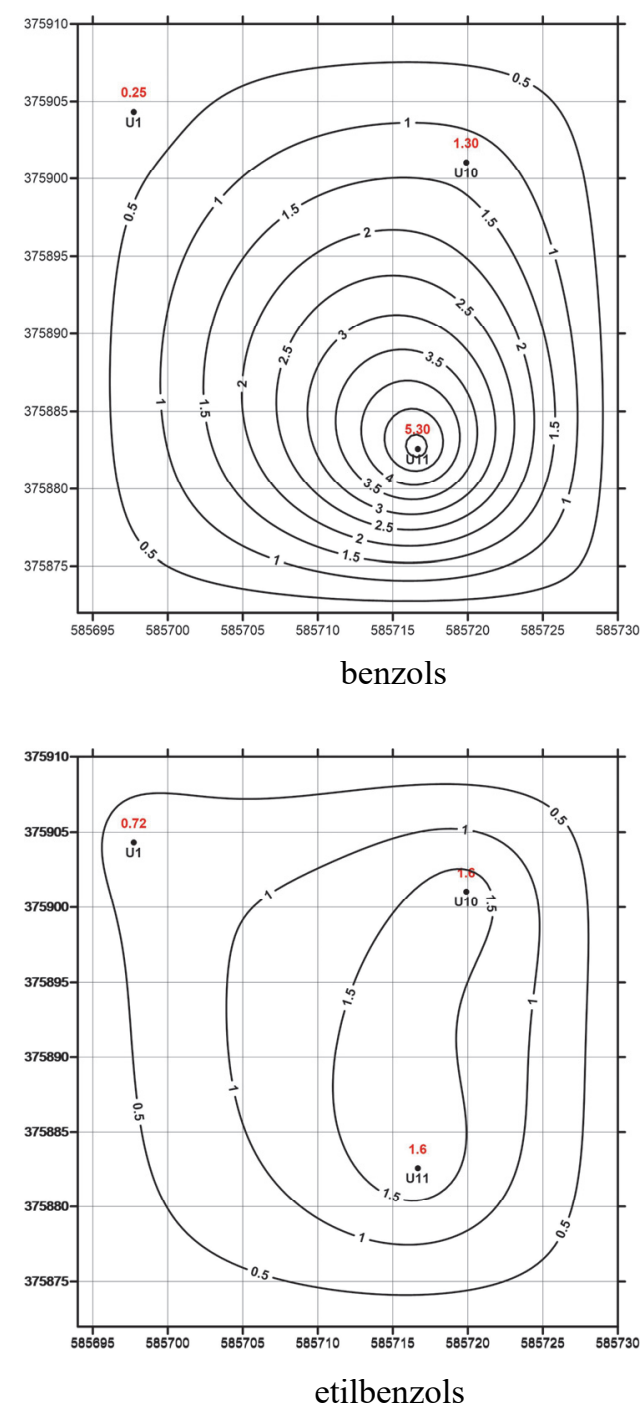
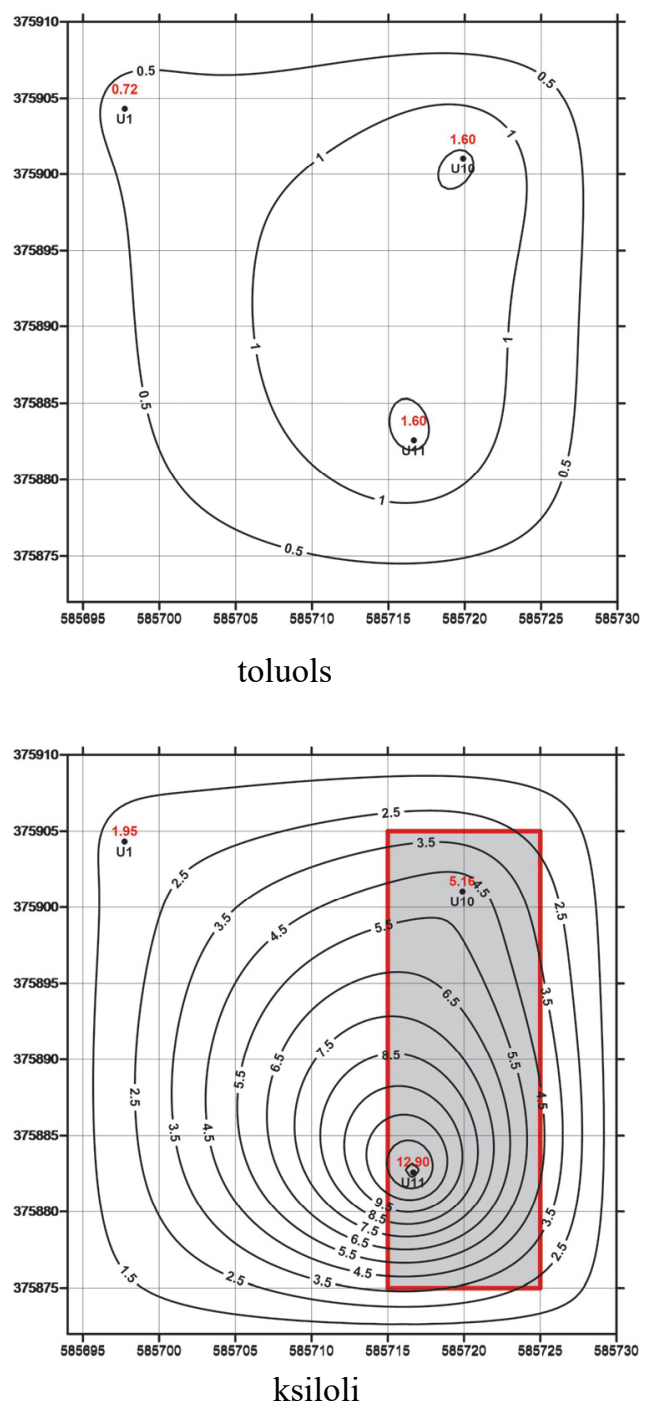

1a. att. Gruntsūdens $B T E X$ komponenšu koncentrācijas aprēḳina apgabalā, mg/m³ ksilolu kartē ietonētas trīs koncentrācijas avota šūnas. 

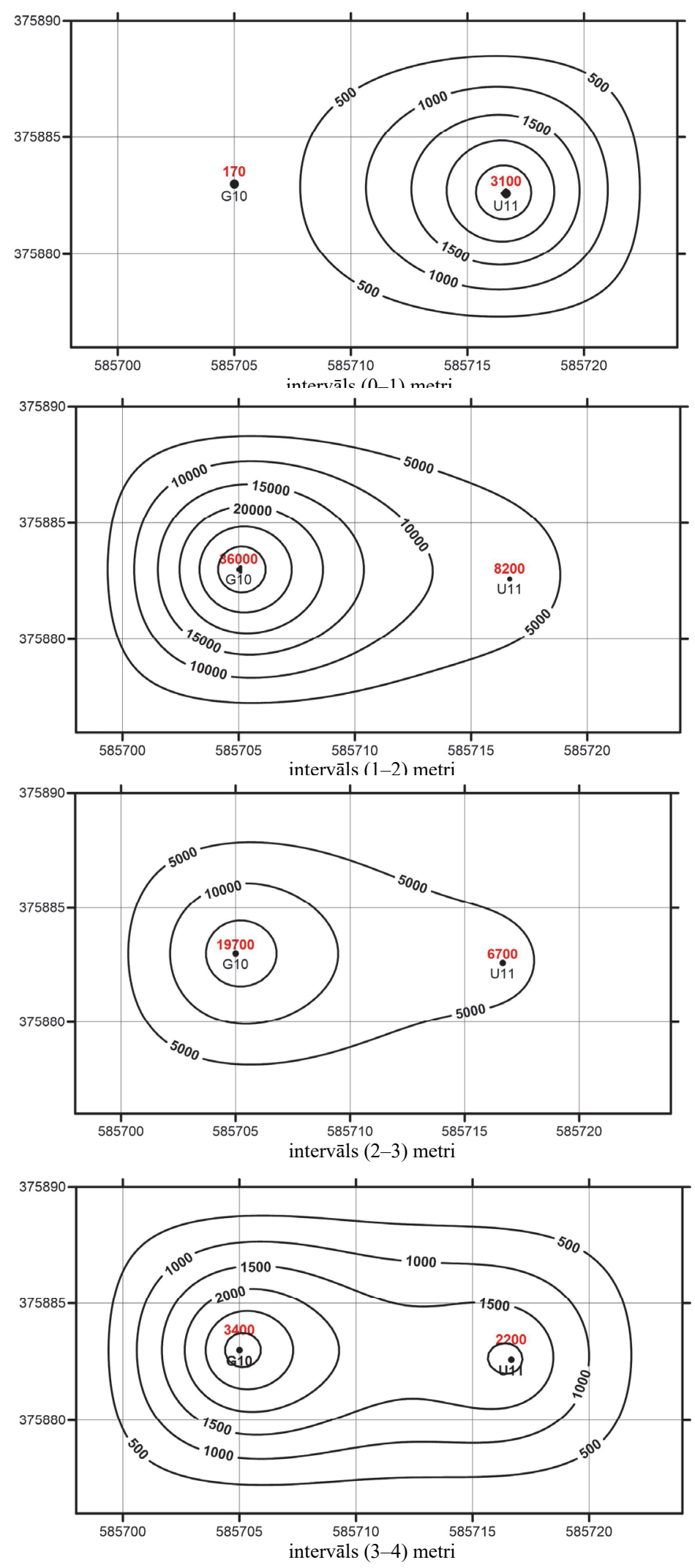

2a. att. Naftas produktu koncentrācija gruntī, mg/kg 


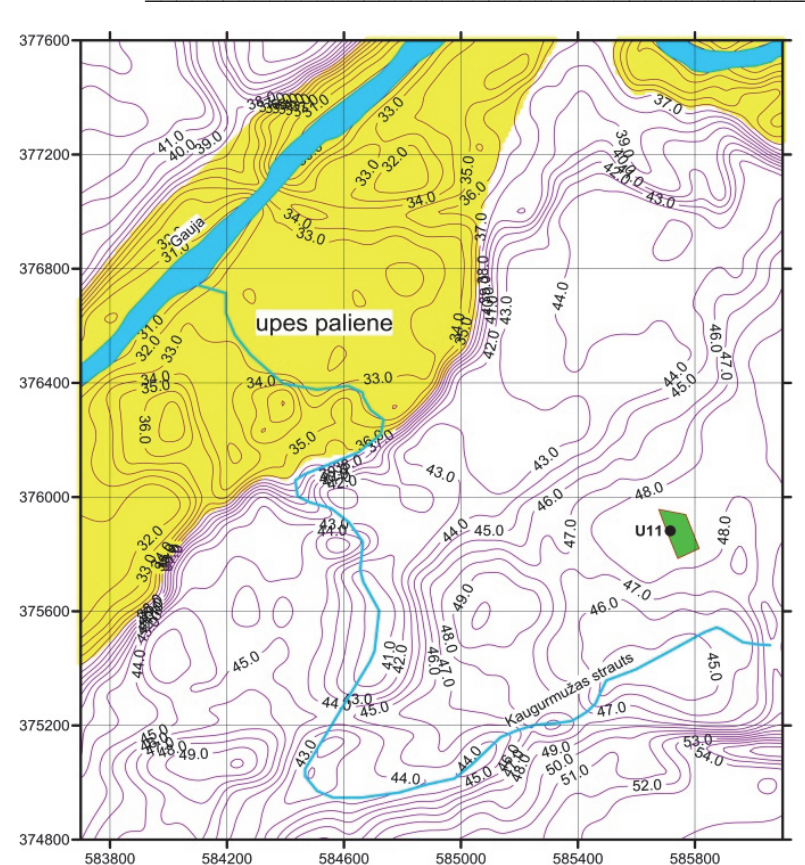

reljefs ar Gaujas upes palieni

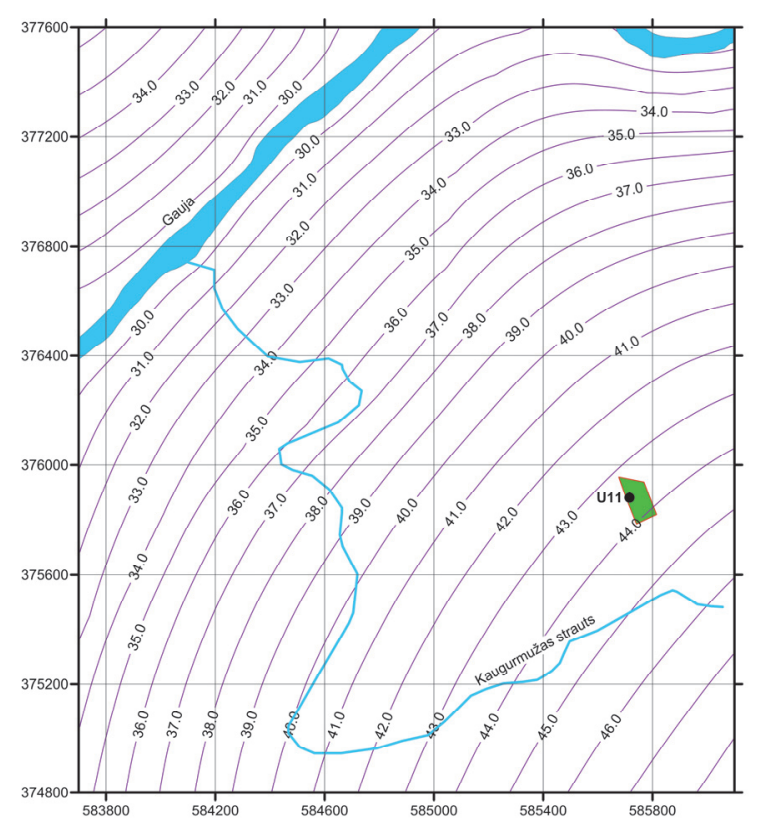

pazemes ūdens līmenu sadalījums D2brt horizontā

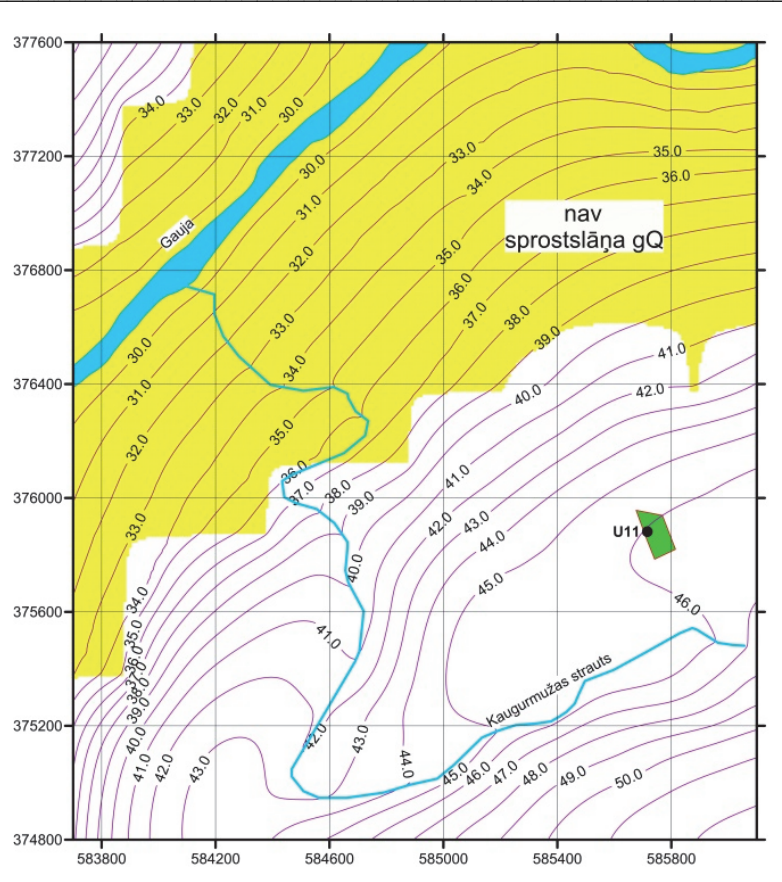

pazemes ūdens līmeṇu sadalījums Q horizontā

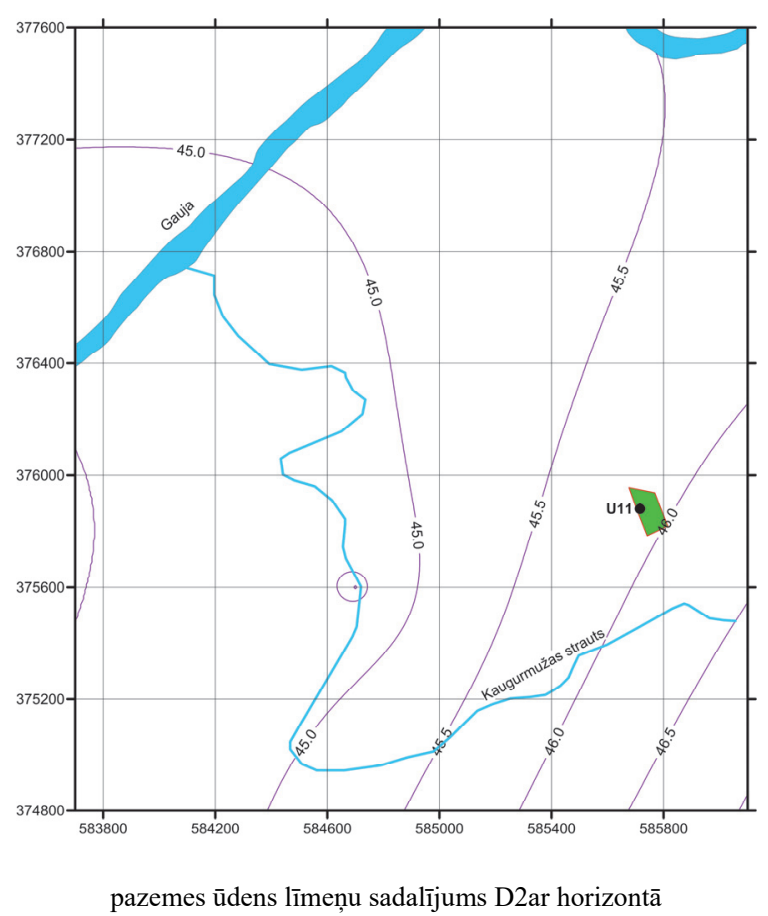

3a. att. Pazemes ūdens līmeṇu sadalījums [m vjl]; izpētes apgabalā_urbumā U11 ir piesārṇojuma maksimums. 


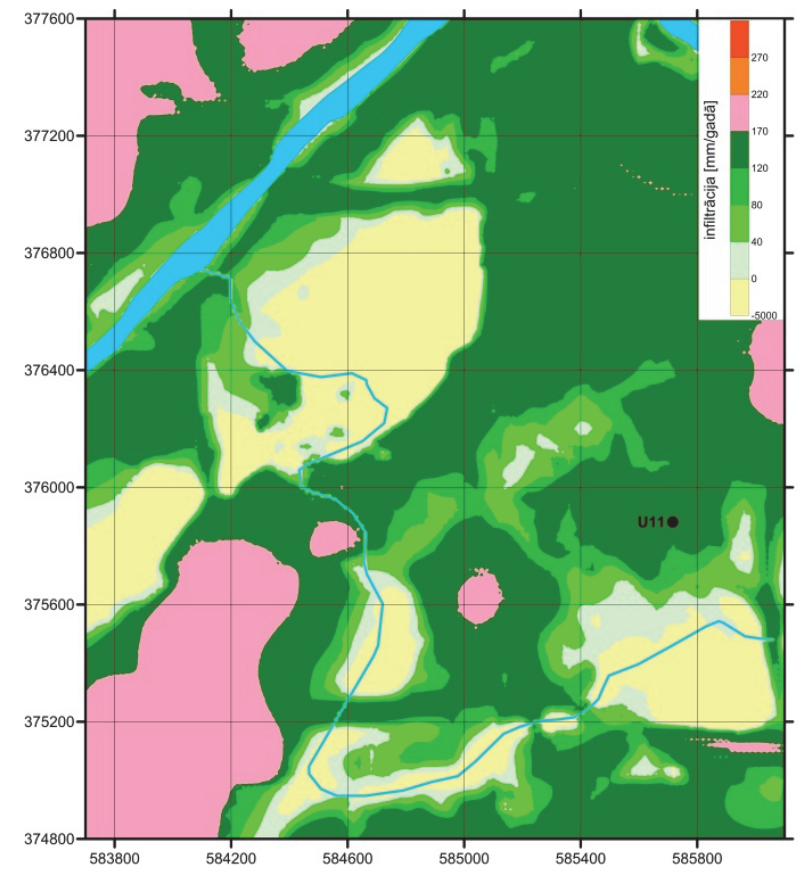

infiltrācijas plūsma Q3 slānī

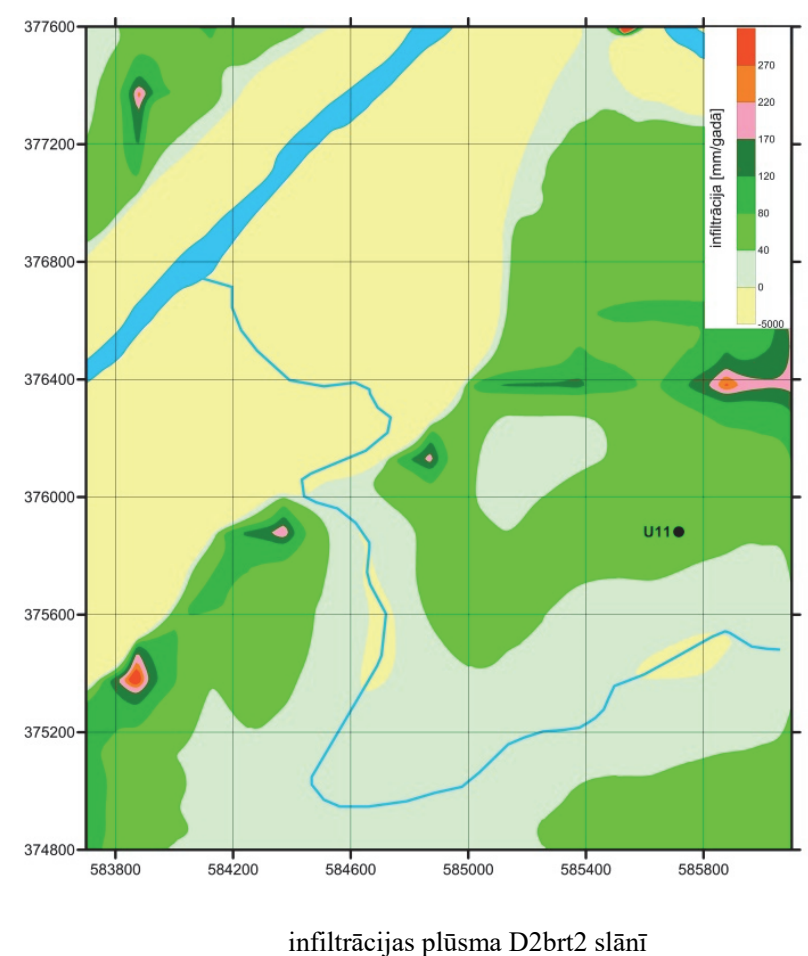

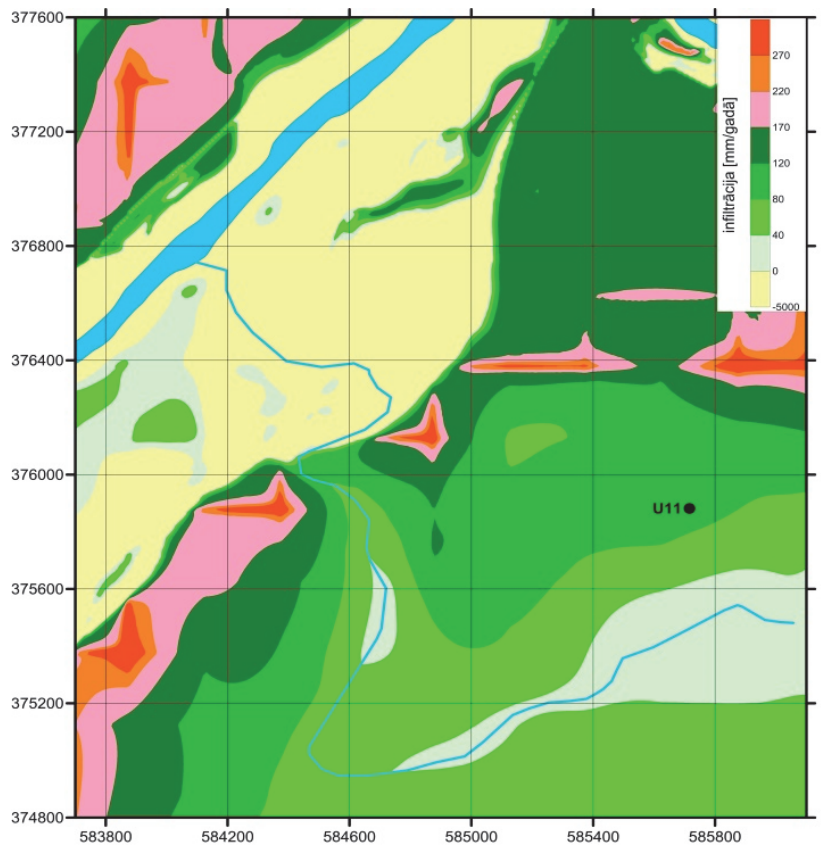

infiltrācijas plūsma D2brt3 slān̄̄

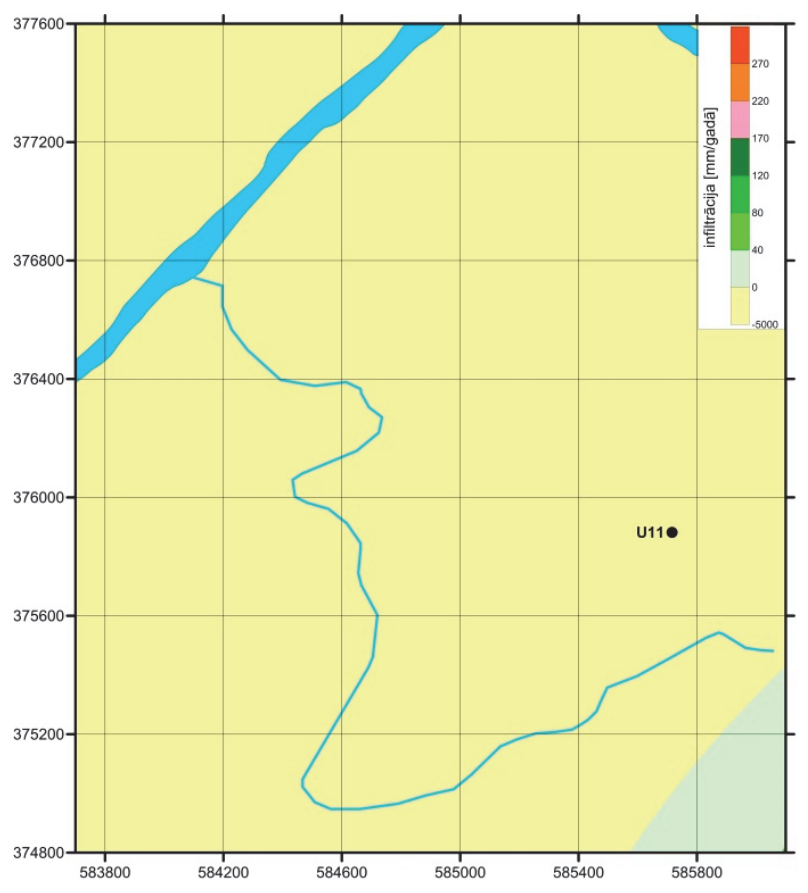

infilttrācijas plūsma D2ar slānī 

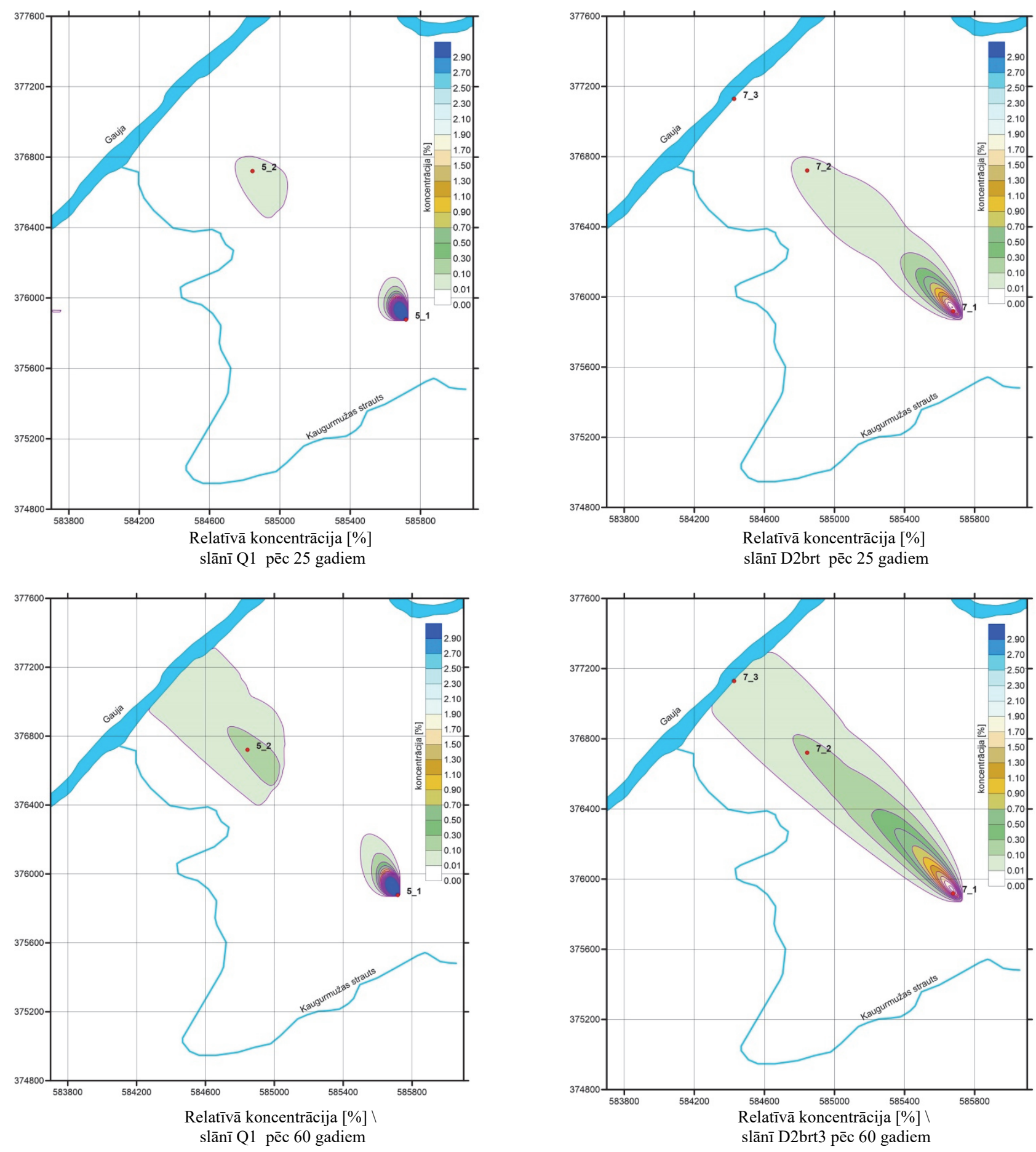

5a. att. Ar programmu MT3D aprēḳinātā relatīvā koncentrācija, \%, pirmajam eksperimentam. 

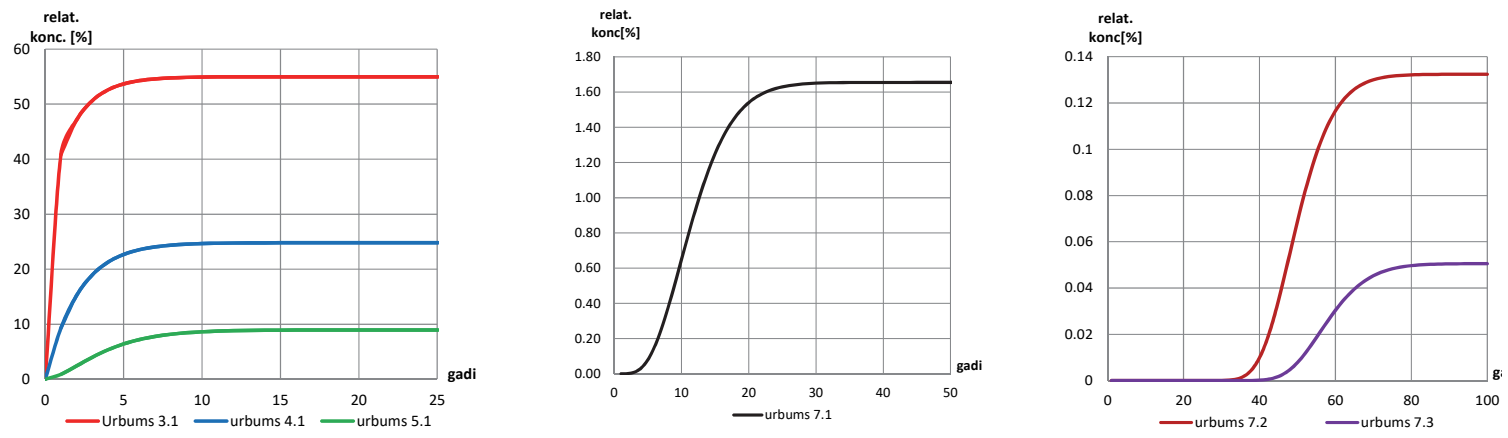

pirmais eksperiments: $C_{\mathrm{r}}=100 \%$
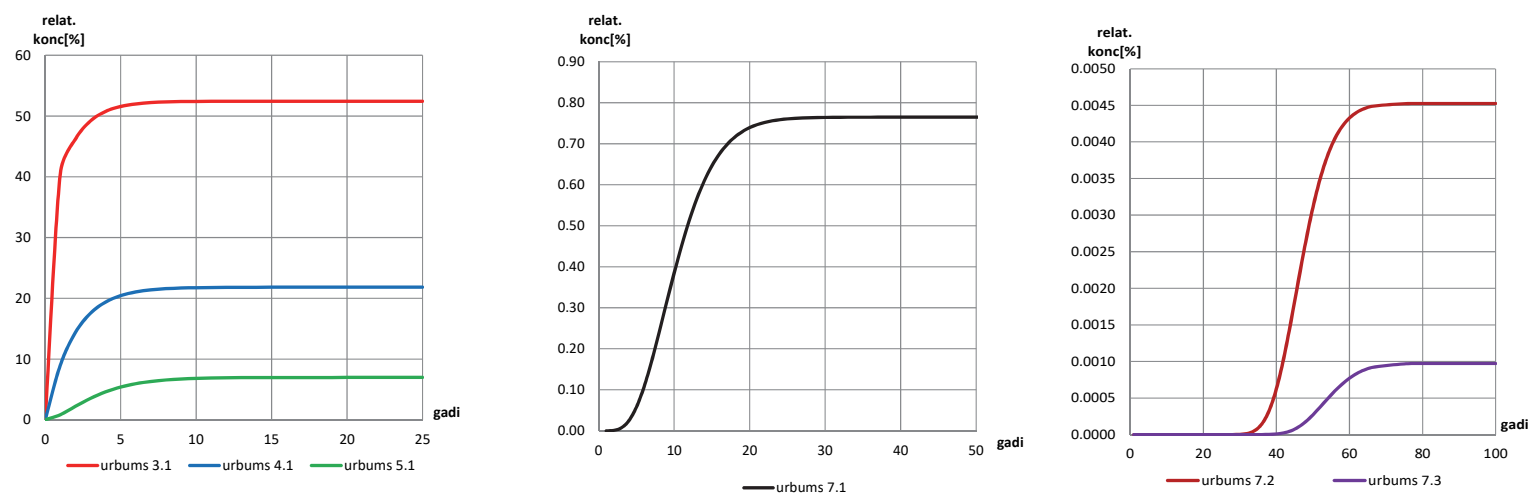

otrais eksperiments: $C_{\mathrm{r}}=100 \%, t_{0.5}=10$ gadi
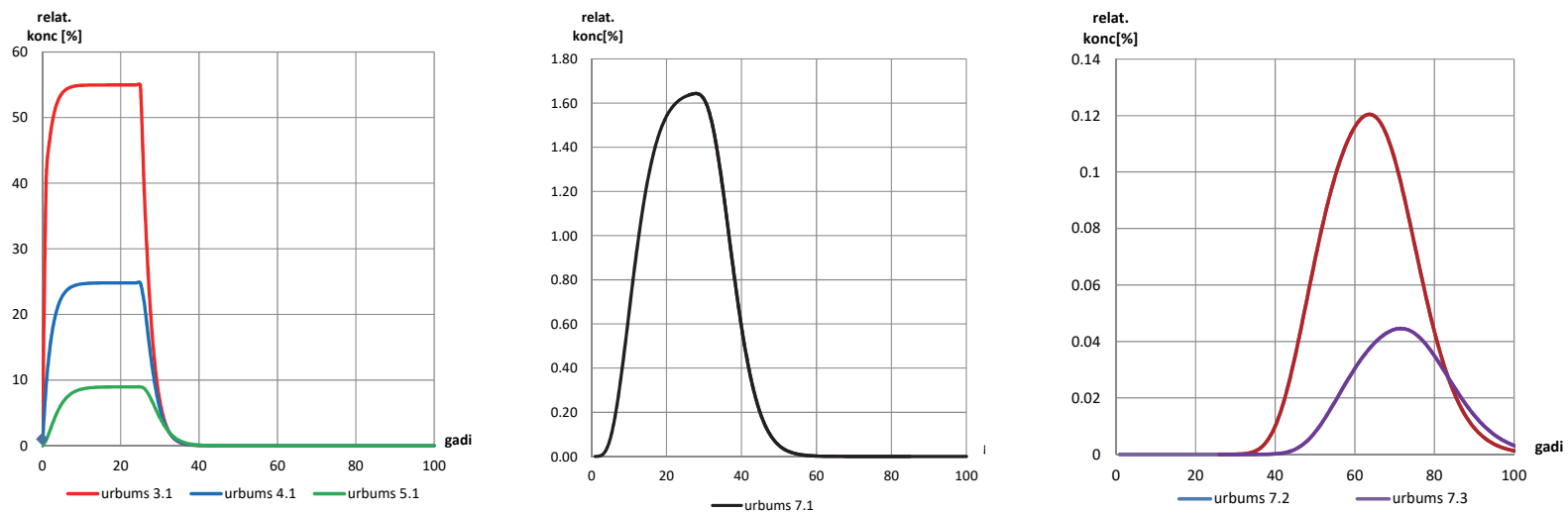

trešais eksperiments: $C_{\mathrm{r}}=100 \%$, pēc 25 gadiem likvidē $C$ avotu

6a. att. Ar programmu $M T 3 D$ aprēḳinātie hidrogrāfi monitoringa urbumiem. 